discurso (33), 2003: 105-52

\title{
Negação e finitude na fenomenologia de Sartre*
}

\section{Luiz Damon Santos Moutinho**}

Resumo: Este artigo investiga o conceito sartriano de negação procurando mostrar o aspecto nuclear desse conceito na fenomenologia de Sartre.

Palavras-chave: Sartre - negação - finitude - liberdade - fenômeno

Ao fazer o elogio da liberdade cartesiana, é a idéia de negatividade que Sartre destaca. Destaque tanto mais curioso, porque, ao lado dele, vai a observação de que o negativo, entre os clássicos do século XVII, deve dissolver-se diante do infinito positivo. No entanto, Sartre insiste nesse destaque, a ponto de ver no negativo cartesiano uma "prefiguração da negatividade hegeliana" (Sartre 15, p. 326). Essa vinculação soa estranha, capaz de provocar um certo mal-estar no leitor cioso da história da filosofia - por isso mesmo, ela pode soar, a princípio, como uma simples caricatura, uma ênfase retórica. Mas não é de retórica que se trata - e o leitor tem aqui todos os motivos para prolongar seu estado de ânimo. Nosso interesse é procurar dissolver, ao menos em parte e por meio de um cruzamento de algumas linhas da história da filosofia, esse compreensível mal-estar.

* Agradeço a Vinicius de Figueiredo as sugestões e críticas valiosas que contribuíram para a versão final deste artigo.

*** Professor do Departamento de Filosofia da UFPR. 


\section{I}

Que entende Descartes por liberdade?, pergunta-se Sartre. Sabe-se que não é na ação ou na vida política que Descartes vai apontar a experiência privilegiada da liberdade. Como metafísico, ele vai encontrá-la noutro lugar, na descoberta da Verdade, mais precisamente, na experiência de um "pensamento autônomo que descobre por suas próprias forças relações inteligíveis entre essências já existentes" (Sartre 15, p. 314). É no "pensamento autônomo" que se encontra a liberdade, e os franceses, que ainda vivem sob o signo de Descartes, prossegue Sartre, costumam entendê-la como um "ato de julgar", como liberdade de julgamento (id., ibid., p. 315). Nem na ação política, nem na moral, portanto; a liberdade cartesiana define-se antes pela ação de um entendimento puro que traz à luz verdades encobertas.

Para Sartre, a palavrinha-chave é autonomia. Mas que pode significar autonomia, pergunta-se ele, quando diante dela se põe uma ordem já estabelecida de relações a descobrir, quando ela pode apenas dizer "sim" àquilo que já é dado, quando ela não é criadora - em suma, quando ela pode apenas assentir? Na curiosa observação de Sartre - e, diga-se logo, flagrantemente anacrônica -, a autonomia do sujeito cartesiano não parece casar-se bem com a mera possibilidade de assentir. De modo que, a despeito da liberdade de intelecção, nada é mais rigoroso, em Descartes, do que o caminho a percorrer. Como um homem que atravessa uma trilha bastante estreita em que todos os seus passos e a posição de seu corpo são condicionados pela natureza do solo e as necessidades da marcha, mas que, não obstante isso, é penetrado pela inquebrantável convicção de realizar livremente todos esses atos, também o sábio cartesiano é penetrado por essa mesma convicção, embora tudo seja fixado "a priori" (id., ibid., p. 316).

O problema aqui é saber como conciliar esses dois aspectos: a necessidade das essências e a autonomia do sujeito. É verdade que se poderia "sacrificar a subjetividade", o que, segundo Sartre, teria feito Espinosa: o verdadeiro se desenvolveria então por sua própria potência, "através dessas individualidades incompletas que são os modos finitos" (id., ibidem). 
Ora, mas é justamente esse salto que Descartes não dá, e por isso vamos encontrar nele uma dupla teoria da liberdade - dupla teoria que tem apenas "a aparência de uma doutrina unitária" (Sartre 15, p. 317). A primeira delas, de inspiração agostiniana (e que, ao que parece, remontaria a Gibieuf), encontramos sobretudo nas Meditações; a segunda, surgida depois da vigorosa reação do Augustinus (1640), de Jansênio, estaria mais próxima da versão dos jesuítas e molinistas e é encontrada nos Princípios (1644) e nas cartas desse período. No primeiro caso, temos uma "liberdade racional" (Sartre não usa essa expressão); no segundo, uma "liberdade de indiferença". De um lado, a ênfase no poder de julgar e dizer o verdadeiro, de assentir e dizer "sim", o que traduziria uma prioridade do entendimento sobre a vontade; de outro, a ênfase na autonomia do sujeito, o que traduziria uma prioridade da vontade sobre o entendimento, em que a "indiferença" se afirma mesmo diante da graça divina e das idéias claras e distintas.

Pela análise da Quarta meditação, Sartre desenvolve a primeira das teorias. Afinal, o próprio Descartes nos diz ali que quanto mais eu pender para o lado da evidência indicada pelo entendimento, tanto mais livremente eu farei minha escolha, e que, ao contrário, a indiferença (a essa altura, "indiferença" significa o não ser impelido para um lado mais do que para outro) "é o mais baixo grau de liberdade". E essa indiferença, acrescenta ele, atesta antes "uma carência no conhecimento do que uma perfeição na vontade" (Descartes 1, p. 119). Eis aqui a "liberdade racional": em termos cartesianos, ela significaria que a vontade é iluminada pelo entendimento, que a vontade, embora livre, deve seguir a evidência indicada por este. Certamente, lembra Sartre, para que chegue o reino da verdade, é preciso que o homem a afirme: o verdadeiro é coisa humana, no sentido em que devo afirmálo para que ele exista. Antes de meu juízo, há apenas idéias neutras, que não são nem verdadeiras nem falsas, de modo que é por mim, é pelo homem, que a verdade aparece no mundo; é por ele que a ordem do ser se transforma em um sistema de idéias, em uma ordem de verdades (Sartre 15, p. 317). E isso, frisa nosso filósofo-leitor, requer uma "liberdade construtiva" (id., ibid., p. 320): as regras do método, salvo a primeira, não são, afinal, "máximas de invenção"? (id., ibid., p. 321). Entretanto, se é preciso o juízo humano, uma 
afirmação construtiva e criadora para que a ordem do ser se transforme numa ordem de verdades, é certo também que sou irresistivelmente levado a afirmá-las: "Se digo que eu não existo, eu não forjo nem mesmo uma ficção" (Sartre 15, p. 322). Ainda a Quarta meditação, em trecho citado por Sartre: "Examinando, estes dias passados, se alguma coisa existia no mundo e reconhecendo que, pelo simples fato de examinar esta questão, decorria necessariamente que eu próprio existia, não podia impedir-me de julgar que era verdadeira uma coisa que concebia tão claramente, não que a isso me achasse forçado por alguma coisa exterior, mas somente porque a uma grande clareza que havia em meu entendimento seguiu-se uma forte inclinação em minha vontade; e fui levado a acreditar com tanto mais liberdade quanto me encontrei com menos indiferença" (Descartes 1, p. 119). Diferentemente de Kant, para quem "o espírito humano constitui a verdade", encontramos em Descartes uma "ordem preestabelecida" (Sartre 15, p. 321) malgrado o caráter construtivo da liberdade, ela consiste em uma "irresistível adesão à evidência" (id., ibid., p. 322). Há aqui, segundo a leitura sartriana, uma inversão na relação entre vontade e entendimento: quando se trata da evidência, este último passa a ter prioridade sobre aquela. Onde está a vontade livre? Não basta responder que essa irresistível adesão positiva é livre porque se faz sem nenhum constrangimento externo, porque, enquanto assunto da alma, é livre do terreno das paixões, porque, enfim, as idéias claras e distintas são idéias de nosso próprio entendimento. Não, de modo algum. Pois não basta, para Sartre, desvincular o ato de uma necessidade externa e mostrar que a idéia identifica-se com a espontaneidade de nosso espírito (Teixeira 17, p. 61), porque, ainda aqui, a liberdade depara com uma rigorosa necessidade: ela não é - eis o que Sartre quer apontar - uma produtividade, isto é, uma criação. Assim, o que subjaz à crítica sartriana é a equivalência entre ato autônomo e ato criador, de modo que por liberdade (sartriana, dessa vez) deve-se entender a livre criação de uma nova ordem. Para Descartes, ao contrário, a evidência necessária não faz senão "aumentar e fortalecer minha liberdade", já que ela permite superar a "indiferença". A equação cartesiana, como se sabe, não se fecha sem um recurso final ao infinitamente infinito. É isso que vai permitir a Sartre aproximar a 
luz natural da luz sobrenatural. "No fundo", diz ele, "não há grande diferença entre a luz natural e esta luz sobrenatural que é a graça" (Sartre 15, p. 324), entre o conhecimento e a graça divina. Por que essa aproximação? Por que, em ambos os casos - e residiria aqui o traço "agostiniano" da "liberdade racional" -, a vontade é subsumida? Ou antes: por que, em ambos os casos, a "indiferença" (que vai ao ponto de significar "poder dizer não", "poder pecar") é subsumida ao não poder dizer não, não poder pecar, em virtude da evidência e da graça? Na verdade, importa a Sartre, ao explorar essa aproximação, não tanto apontar a origem agostiniana do conceito de liberdade - e, conseqüentemente, o caráter enfermo da vontade, a miséria do homem sem a graça etc. -, trata-se antes de mostrar que essa primeira versão da liberdade aponta uma subsunção absoluta da finitude, de modo que a contradição com a segunda versão - a da autonomia - torne-se mais nítida. A "liberdade racional", em suma, nos permite vislumbrar o elo entre finito e infinito - ou a tentativa de conciliação entre uma metafísica racionalista e uma teologia cristã. Assim, quando Descartes observa que, para ser livre, não é necessário ser indiferente, que, ao contrário, eu serei tanto mais livre quanto mais eu pender para um dos dois contrários, seja porque, continua ele, "eu conheça evidentemente que o bom e o verdadeiro aí se encontrem, seja porque Deus disponha assim o interior do meu pensamento" (Descartes 1, p. 118), quando Descartes diz isso, é sobretudo para o segundo termo da alternativa que Sartre quer chamar a atenção. Nesse caso, tanto nos atos de fé - em que "a vontade é inteiramente penetrada e iluminada por uma luz interior e sobrenatural que se chama a graça" (Sartre 15, p. 324) -, quanto no conhecimento natural - quando o entendimento conhece com evidência "o bom e o verdadeiro" -, em ambos os casos, o entendimento não pode ser razão suficiente: não é apenas no ato de fé que o entendimento é insuficiente e o infinito intervém, é também no conhecimento da evidência. Pois, afinal, é de Deus, não de mim - eu que "sou nada" -, que a idéia tira seu ser. Deus é a "fonte de todo ser e de toda positividade" (id., ibidem), dessa idéia que pesa sobre mim e à qual eu não posso senão assentir. Certamente, a graça divina nos afeta apenas ali onde o entendimento não basta, mas resta que, num caso como no outro, Deus é a fonte de todo ser. 


\section{II}

Mas essa teoria, como dissemos, não esgota ainda a doutrina cartesiana da liberdade, segundo Sartre. Haveria uma outra, "bastante diferente", pela qual Descartes procuraria "salvar a autonomia do homem" (Sartre 15, p. 317). O "oportunismo" de Descartes estaria aqui, na medida em que ele procuraria escamotear o antigo papel da indiferença, ressaltando-o agora a ponto de sublinhar a indiferença mesmo diante da graça. Assim, por exemplo, pode-se mostrar que no parágrafo 41 dos Princípios, Descartes fala da liberdade $e$ da indiferença indistintamente, "sem estabelecer entre uma e outra a diferença de grau que se encontra na Quarta meditação"(1): "Nós estamos assim de tal modo seguros da liberdade $e$ da indiferença que está em nós, que não há nada que conheçamos mais claramente" (Descartes 3, p. 589; grifo nosso). Ora, aparentemente Sartre está de acordo com a idéia de um "oportunismo" de Descartes, pois logo depois de ter citado essa mesma passagem, lembrando que ela volta a nos conceder a liberdade de indiferença, ele acrescenta: "Mas é uma simples precaução [de Descartes]: o temível sucesso do Augustinus tinha lhe trazido inquietudes, e ele não queria arriscar-se a ser condenado na Sorbonne" (Sartre 15, p. 324-5). "Simples precaução": Descartes, de fato, faria concessões ao momento político; entretanto, não é tanto na nova versão da indiferença, mais próxima da teoria dos jesuítas, que vamos encontrar a segunda teoria da liberdade. Essa segunda teoria já se encontra, de maneira muito mais radical, no simples exercício da dúvida, que vai se tornar então, para Sartre, o "tipo mesmo do ato livre" (id., ibid., p. 326). É assim que a autonomia, sempre na leitura de Sartre, vai se confundir com uma simples negatividade - no caso, com o poder "de dizer não a tudo o que não é o verdadeiro" (id., ibid., p. 317). Se não há invenção criadora, pois a ordem é já preestabelecida, resta, contudo, o poder de dizer "não", resta a recusa, resta o poder de escapar, de se desviar, de se retirar - resta a negatividade. Mas trata-se aqui de uma recusa do falso, do truncado, do confuso, do erro, em suma, do não ser. ${ }^{(2)}$ É em relação a isso que eu conservo, enfim, uma liberdade de indiferença; apenas aqui, 
acredita Sartre, a autonomia é conservada. Mas autonomia em relação ao truncado, ao falso - isto é, ao não ser. Nesse caso, o que Descartes põe em relevo é a liberdade como poder de escapar, de recusar, de dizer "não", a liberdade como potência negativa, "prefiguração", assegura Sartre, "da negatividade hegeliana” (Sartre 15, p. 326). É, enfim, a dúvida como suspensão do juízo, negação pura. Ora, ocorre que, no momento mesmo em que o homem atinge uma inigualável independência, contra o Gênio Maligno, contra Deus, ele se surpreende apenas como um nada, como um puro não, sem corpo, sem lembrança, sem saber - sem que daqui, por si mesmo, ele possa ir além. Essa negação, sem dúvida, vai merecer todos os elogios de Sartre: ninguém antes de Descartes, diz ele, tinha apontado uma tal ligação entre o livre-arbítrio e a negatividade, ninguém tinha mostrado que o homem é livre não enquanto é um pleno de existência, mas enquanto não é, enquanto é negação. Acontece, contudo - eis aqui os limites de uma metafísica do infinito -, que essa negatividade nada produz. Ela é limitada, em última instância, pelo fato mesmo de que a idéia tem um ser que eu não posso lhe dar - e quando um tal ser aparece, com todo seu peso e absoluta positividade, "não podemos recusar-lhe nossa adesão" (id., ibid., p. 327). Essa substância que se afirma contra Deus mostra ser dele inteiramente dependente.

\section{III}

Eis, enfim, na perspectiva de Sartre, as duas teorias da liberdade de Descartes, convivendo sob a aparência de uma unidade. De um lado, a liberdade como adesão positiva - e, nesse caso, a clareza e distinção da idéia concebida pelo entendimento determinam a vontade, o que, para Sartre, implica a perda da autonomia. De outro, a liberdade negativa, que preserva a autonomia, mas que se reduz a uma recusa do falso, do erro, do Mal, isto é, do não ser. Se, diante disso, ainda se pode dizer que o homem cartesiano é livre, seria preciso dizer, do ponto de vista de Sartre, que ele é livre para o 
Mal, não para o Bem; para o Erro, não para a Verdade, ou melhor, que ele é livre para a recusa do Mal e do Erro. Pois, diante do Bem e da Verdade, não lhe resta senão uma adesão positiva, já que a vontade, conforme a luz natural, segue a evidência indicada pelo entendimento. Assim, uma visão clara do Bem implica o ato tal como a visão distinta do Verdadeiro implica o assentimento. Nosso ato, desse ponto de vista, será o mais completamente livre quando ele for o mais conforme à ordem universal (Sartre 15, p. 325).

Aqui, contudo, seria o caso de perguntar se o papel novo que Descartes concede à indiferença, nos Princípios e nas cartas do mesmo período, não vai além dessa simples negatividade que Sartre localiza já no exercício da dúvida. Pois, enfim, ela parece ir além não só da indiferença da Quarta meditação, que a tomava como uma simples indeterminação, como também dessa negatividade tomada como um poder de recusa. Com efeito, três anos depois das Meditações, nos Princípios (1644), Descartes parece dar um passo adiante quando afirma: "É tão evidente que nós temos uma vontade livre, que pode dar seu consentimento ou não quando bem lhe parecer, que isso pode ser contado por uma de nossas mais comuns noções" (Descartes 3, p. 588). E em duas cartas ao Padre Mesland, de 2 de maio de 1644 e de 9 de fevereiro de 1645 , ele é ainda mais preciso. Há, de um lado, a indiferença como "estado", que consiste, diz na carta de 1645, "no estado no qual se encontra a vontade quando nenhuma percepção do verdadeiro ou do bem a impele para um lado antes que para outro" (id., ibid., p. 1177). É a essa idéia de indiferença que se referia a Quarta meditação quando a indicava como o mais baixo grau de liberdade. Mas há uma outra idéia de indiferença, em que ela é tomada agora como uma "faculdade positiva" de se determinar por qualquer um dos contrários, para procurá-lo ou fugir dele, para afirmá-lo ou negá-lo, e isso não só naqueles atos em que nenhuma razão evidente impele a vontade, mas também, como afirma Descartes, "em todos os outros". "Sempre nos é possível parar de procurar um bem claramente conhecido ou de admitir uma verdade evidente" (id., ibid.). Posso, enfim, seguir o pior, mesmo vendo o melhor. Aqui, a indiferença não é mais aquela carência de conhecimento a que se referia a Quarta meditação, mas uma "faculdade positiva" de se determinar, um poder de "sim" e de "não" - poder que se 
afirma mesmo diante das idéias concebidas pelo entendimento, mesmo diante das idéias claras e distintas. Ora, mas se é assim, se se concede uma significação positiva à liberdade de indiferença, para além daquilo que a Quarta meditação indicava, quando não havia ali nenhuma evidência, e para além da negatividade de que fala Sartre, resta que sempre haverá uma contradição entre, de um lado, a "liberdade racional", que consiste em obedecer à evidência indicada pelo entendimento, e, de outro lado, a liberdade como faculdade positiva de não obedecer a essa evidência. Como Descartes resolve essa dificuldade? E, quanto a Sartre, isso não deveria levá-lo a alargar a "negatividade" cartesiana? Afinal, ali onde ele aponta uma recusa apenas do não ser, Descartes aponta o poder de dizer não também ao ser.

Esse novo aspecto, contudo, não escapou a Sartre. Discutindo a segunda versão da liberdade cartesiana, ele diz: "Chamávamos liberdade (...) a possibilidade para a vontade de dizer sim ou não diante das idéias que concebe o entendimento" (Sartre 15, p. 323). Contudo, ainda que aponte também esse aspecto, Sartre desenvolve apenas o primeiro. É que a própria solução cartesiana, do ponto de vista em que Sartre se põe, parece conduzir apenas àquele outro, o da negação do não ser. Com efeito, segundo Descartes, é necessário considerar a liberdade antes e durante o ato. Antes de decidir, a vontade tem o poder de escolher entre um e outro lado, ela é portanto indiferente, mesmo que um dos lados seja uma evidência: eis aí a liberdade de indiferença entendida como "faculdade positiva". Depois que escolhe, isto é, durante a realização do ato, já não há indiferença. A vontade passa a seguir a evidência indicada pelo entendimento - trata-se então da "liberdade racional" (Descartes 3, p. 1177). A distinção entre a liberdade de indiferença e a liberdade racional passa por ser agora, portanto, a diferença entre as "ações da vontade" antes da realização do ato e durante a realização do ato. E a liberdade de indiferença das Meditações é agora a liberdade como simples estado, não como um poder positivo. Se essa solução nada muda, uma vez que o leitor tenha se posto na perspectiva de Sartre, é porque o poder de recusar a evidência só é reconhecido antes do ato. A passagem ao ato vai acarretar, de todo modo, o que Sartre entende como perda de autonomia. É por isso que a recusa vai ser sempre recusa apenas do não ser. A passa- 
gem ao ato vai necessariamente acarretar a afirmação do ser dado - ou será, antes dela, uma recusa do não ser.

Essa solução, contudo, parece girar em falso. Afinal, que significa dizer que eu posso recusar a evidência apenas antes do ato? Nesse caso, não posso afirmar o falso, isto é, não posso seguir o pior, mesmo vendo o melhor. Sim, posso, mas aqui é necessário observar, de início, que o pecado está ligado a um estado de confusão e de indeterminação, não a uma visão clara de que o que fazemos é mau (Teixeira 17, p. 65). É exatamente por isso, diz Lívio Teixeira, que se pode refutar a tese de oportunismo de Descartes, uma vez que ele não vai até o ponto de afirmar, como os jesuítas, que o pecado acarreta a visão clara da má ação. E, depois, ali onde há recusa da evidência, Descartes a vincula - o que é fundamental - a um fim preciso, como ele afirma na carta a Mesland de 1645: "Somos livres de nos impedir de procurar um bem que nos é claramente conhecido, ou de admitir uma verdade evidente, desde", acrescenta ele, "que pensemos que é um bem testemunhar, por esse meio, a liberdade de nosso livre-arbítrio" (id., ibid., p. 69; grifos nossos). A recusa da evidência está ligada à afirmação da prioridade da vontade, a uma afirmação do livre-arbítrio, não a uma afirmação do falso ou ao pecado: seguir o pior significa aqui apenas a afirmação da primazia da vontade. É aqui que se pode ver quão longe está Descartes da tese jansenista de uma incapacidade essencial da vontade, provinda da queda do homem. E, se se recua às Meditações, como faz Lívio Teixeira para mostrar a "congruência" da doutrina cartesiana, pode-se recusar a tese de que ali onde há evidência e graça simplesmente não haja vontade. Certamente, não há indiferença, mas nem por isso a vontade é ali menos forte (id., ibid., p. 64-5). Na solução de Lívio Teixeira, é preciso distinguir, portanto, vontade e indiferença, e, se Descartes vai ao ponto de afirmar o poder positivo de determinação, isso não acarreta a afirmação de que o pecado está vinculado à visão clara de que o que fazemos é mau. Descartes retoma, em carta a Mersenne, o velho adágio omnis peccans est ignorans. O que se vê em Descartes, portanto, é, indistintamente, uma afirmação da primazia da vontade (mesmo que para recusar-se ao bem, para determinar-se "absolutamente", ainda que "moralmente" outro caminho seja indicado) (Descartes 3, p. 1177), primazia 
atestada pelo seu caráter ativo, em face do caráter passivo do entendimento, e de que "é principalmente por ela que ao homem pode ser atribuída a qualidade de ser uma imagem de Deus" (Teixeira 17, p. 67).

Há, de fato, congruência nessa teoria? Sartre crê que não. Mas sua objeção, diferentemente do debate entre os comentadores, consiste em exigir de Descartes aquilo que ele parece não poder dar: uma finitude sem referência ao infinito. Daí por que se trata para Sartre de levar ao limite a idéia de autonomia, o que a "indiferença" cartesiana diante da evidência (não como simples estado, mas como faculdade positiva) ainda não faz. No caso, uma autonomia sem dependência em relação a uma substância primeira. Sendo assim, em que a intuição cartesiana pode ainda interessar a Sartre? É que o próprio Descartes intuiu a verdadeira autonomia. É verdade que ele não "sacrifica" a subjetividade - daí a "indiferença", daí a "negatividade" -, mas não é no sujeito que ele vai até o limite da idéia de autonomia: é em Deus, é na liberdade divina que vamos encontrar esse desenvolvimento. Eis aí o que vai interessar a Sartre: não apenas a negatividade, mas também um certo traço que Descartes "sublima" em Deus, pois Sartre procura no sujeito não apenas um ponto de partida, não o primeiro elo na cadeia das razões, mas, muito além disso, o próprio absoluto. O que visa Sartre aqui é nada mais, nada menos que, por uma estranha reviravolta, mostrar a negatividade, a nadificação, como produtora. Mas como pode a negatividade ser produtora, como ela pode transfigurar-se em criação, em afirmação, em positividade?

\section{IV}

Vimos o que nos diz Descartes lá na Quarta meditação: a liberdade de Deus não é mais inteira que a do homem. É a vontade que, do ponto de vista formal, marca nossa semelhança com Deus, na medida em que ela é poder absoluto de sim e de não, em mim e nele. Diz Descartes: "Eu sinto ser 
[a vontade] em mim tão grande, que não concebo absolutamente a idéia de nenhuma outra mais ampla e mais extensa: de sorte que é principalmente ela que me faz conhecer que eu trago a imagem e a semelhança de Deus. Pois, ainda que seja incomparavelmente maior em Deus do que em mim, (...) ela não me parece, todavia, maior se eu a considero formal e precisamente nela mesma" (Descartes 1, p. 118). A liberdade é infinita, "semelhantemente infinita", em todos os homens. Por isso, ela está além da potência de cada um - não importam os acidentes corporais (a memória mais viva, a imaginação mais extensa etc.), a liberdade está além deles. Uma fraca potência não poderia limitar a liberdade: mesmo com uma potência limitada, a liberdade é total; por isso o que importa "é o uso que fazemos livremente desses dons" (Sartre 15, p. 319; grifo nosso), não eles mesmos. A liberdade não é aqui, portanto, um poder fazer; ela é um livre querer - formalmente infinito, absoluto. E, se a liberdade divina é semelhante à liberdade humana, concluirá Sartre, talvez encontremos na liberdade divina o verdadeiro desdobramento lógico do conceito de liberdade, o desdobramento de suas exigências, desdobramento que Descartes, por conta de entraves "dogmáticos", não pôde estender à liberdade humana. É aqui que entram em cena os "postulados filosóficos" de Descartes que não lhe permitiram ir até o fim na idéia de liberdade - entraves tanto mais visíveis, segundo Sartre, porque a liberdade de Deus não é mais completa que a do homem. Teria havido assim, diz Sartre, um fenômeno de "sublimação e de transposição", segundo o qual Descartes teria lançado para a liberdade divina o que é da liberdade pura e simples (id., ibid., p. 331).

Pois, de fato, o Deus cartesiano é o mais livre dos deuses. Ele não é submetido a nenhum princípio - nem o de identidade -, a nenhum Bem soberano quando cria. Sartre cita Descartes: "Para as verdades eternas, eu digo que elas são verdadeiras ou possíveis porque Deus as conhece como verdadeiras ou possíveis e que, ao contrário, elas não são conhecidas como verdadeiras por Deus, como se elas fossem verdadeiras independentemente dele" (id., ibid., p. 332). ${ }^{(3)}$ Tais verdades foram estabelecidas por ele e dele dependem - Deus foi livre e indiferente, eis o que Sartre quer frisar, para fazer que três ângulos de um triângulo fossem iguais a dois retos, e, se Deus 
quis que algumas verdades fossem necessárias, isso não significa que ele as tenha necessariamente querido (Descartes 3, p. 1167). Portanto, é em Deus que finalmente encontramos aquela "liberdade de indiferença", no sentido, precisa Descartes na carta ao Padre Mesland de 2 de maio de 1644, em que Deus é livre para fazer ou não fazer alguma coisa. Mas aqui com um traço fundamental: a indiferença em Deus nem é estado de indeterminação, nem é negatividade, recusa do não ser. ${ }^{(4)}$ "Em Deus", diz ainda Descartes na mesma carta a Mersenne, "é o mesmo querer e conhecer; de sorte que, porque ele quer uma coisa, ele a conhece, e por isso apenas essa coisa é verdadeira. Não se deve dizer que, se Deus não existisse, essas verdades seriam verdadeiras" (Sartre 15, p. 332; Descartes 3, p. 936). Não há negatividade na liberdade divina; esse querer que é idêntico ao conhecer, de tal modo que não há "prioridade entre seu entendimento e sua vontade" (id., ibid., p. 1167), ${ }^{(5)}$ é, conforme Sartre, "pura produtividade, é o ato extratemporal e eterno pelo qual Deus faz que haja um mundo, um Bem e Verdades eternas" (Sartre 15, p. 333). Se o querer é já um conhecer, se o velle é já um videre, então o querer divino é sinônimo de criação, "a consciência divina é ao mesmo tempo constitutiva e contemplativa" (id., ibid.), e foi isso que Descartes compreendeu perfeitamente bem, segundo Sartre: que o conceito de liberdade contém a exigência de uma autonomia absoluta, que um ato livre é não apenas ex nihilo, mas que ele é, por isso mesmo, uma produção absolutamente nova, de modo que liberdade é idêntica a criação (id., ibid., pp. 332-3). É a liberdade o fundamento do verdadeiro, e mesmo a necessidade que aparece na ordem das verdades é sustentada pela contingência absoluta do ato livre. A liberdade é aqui o próprio estabelecimento de uma ordem. A raiz da Razão, diz Sartre, está "nas profundezas do ato livre" (id., ibid., p. 333). O Deus cartesiano não é inclinado, como o Deus de Leibniz, a escolher, por complexo cálculo, o que é o melhor, mas, ao contrário, é graças ao que ele decidiu, por efeito apenas de sua decisão, que o absolutamente bom vem ao mundo. A liberdade não é limitada por nenhuma essência eterna, por nenhuma estrutura necessária do ser. É a liberdade divina, ao contrário, que sustenta tal estrutura, tais essências. Essa liberdade é, assim, o fundamento do ser, a sua dimensão secreta. A mais profunda necessidade não tem seu fun- 
damento senão em um ato livre. Eis o que Sartre entende como um precioso ensinamento cartesiano a ser retido e que será a base essencial do seu humanismo: "O homem é o ser cuja aparição faz que um mundo exista" (Sartre 15 , p. 334).

Ora, que isso significa? Significa que, destronando Deus, o homem tome seu lugar? Que ele seja criador, como o é o Deus cartesiano? Que ele seja criador de ser? Certamente, não. É o que fica mais claro nas objeções de Sartre ao "idealismo" e a sua tese da constituição do ser - que, na versão sartriana da história da filosofia, encarregou-se de não deixar aquele trono vago. Que nos lembremos aqui da Introdução a $O$ ser e o nada, em que Sartre faz a crítica do desvio idealista de Husserl e do idealismo de Berkeley. Seria preciso dizer antes que, se é verdade que apenas na liberdade divina encontramos os desdobramentos da idéia de liberdade, é verdade também, por outro lado, que em Deus não encontramos aquela negatividade entrevista por Sartre - o Deus cartesiano é pura positividade, criador da existência e da essência, do ser e da verdade. Já o homem sartriano é criador, sim, mas, diferentemente do Deus cartesiano, ele é criador a partir de um ato de negação, de nadificação. Essa equação - negação e criação - exige que se comece observando que, para Sartre, o ser não é constituído pela consciência. O homem não produz o ser, não cria o ser, como Deus; ele é negação do ser, e é dessa negação que advém a posição de um mundo fenomenal, de uma ordem das verdades e das essências. Que nos lembremos aqui da estratégia de Sartre, em O ser e o nada, em nos pôr, já de começo, diante de um em si - o que não deixa de ser curioso em quem se pretende "fenomenólogo" -, um ser em si denominado por ele transfenomenal. Trata-se do ser do aparecer que não se reduz à série de aparições. É como se tivéssemos em Sartre, já de início, a recusa em partir do fenômeno - ou, antes, 
o esforço em mostrar que o fenômeno reclama ser (Sartre 13, p. 16 e 29). Foi isso que resultou de seu esforço inicial "em busca do ser" (título da Introdução a $O$ ser e o nada). Assim, Husserl é ali criticado por reduzir o ser ao aparecer, à "sucessão de suas maneiras de ser", e por isso ele é tido como "fenomenista" (id., ibid., p. 27 e 115). O fenômeno, diz Sartre, é um "apelo de ser", ele exige um fundamento "transfenomenal" (id., ibid., p. 16); tal fundamento não é jamais desvelado, ele é condição de desvelamento (id., ibid., p. 15). Há aqui uma passagem do ôntico ao ontológico que impede a redução completa. Daí por que, em termos sartrianos, a consciência sempre implica um ser outro que ela, diferente dela, uma verdadeira transcendência. Ora, foi isso que a Introdução a $O$ ser e o nada mostrou; mas ela não dizia ainda que relação une a consciência e o ser transcendente. ${ }^{(6)}$

A resposta a essa questão só virá na primeira parte da obra, "O problema do nada", quando finalmente nos é dito que a negação é a "rubrica categorial" que ordena e reparte "grandes massas de ser em coisas" (id., ibid., p. 60) - e a consciência aparece como um não radical em face do ser e em face de si mesma. É impossível construir a noção de objeto, diz Sartre, "se não tivermos originalmente uma relação negativa designando o objeto como aquilo que não é a consciência" (id., ibid., p. 222). Se se quiser, só se pode ser consciência de algo se se é, de início, negação desse algo. O objeto é para mim, antes de mais nada, o que eu não sou, ele só pode existir para mim se ele é algo diferente de mim, se ele é um não eu. Toda presença, diz Sartre, envolve uma negação radical como presença diante daquilo que não somos. É presente a mim o que não sou eu. A negação, evidentemente, parte da consciência, não do ser, que repousa na indiferença absoluta (id., ibid.). Assim, para que eu possa mesmo dizer "objeto", é preciso que, de início, uma negação o distinga de mim. É preciso que eu seja negação desse ser para que ele se constitua como objeto, quer dizer, como fenômeno. Assim, Sartre não parte do fenômeno ou de um dado simples em busca da noção de objeto - ele não se põe o problema da síntese porque não há para ele nem uma sucessão temporal de perfis, nem um diverso sensível a partir dos quais seria engendrada a identidade do ser. Há aqui uma economia do que Husserl denominava "um dos principais problemas de Hume", o da unidade da coisa 
idêntica (Husserl 5, p. 250) - problema que justamente fazia do Tratado "o primeiro esboço de uma fenomenologia pura" (id., ibid., p. 225). E Sartre é muito claro sobre isso: não será uma ligação de representações, nem uma irreversibilidade temporal, nem o recurso ao infinito que vai nos permitir constituir o objeto. O recurso ao infinito é o que ele denunciava, logo na abertura de $O$ ser e o nada, como um recurso implícito do fenômeno husserliano. Husserl subverte os dualismos antigos (essência e aparência, ato e potência) para substituí-los por um novo: o do finito e do infinito. A objetividade do fenômeno husserliano, diz Sartre, é fundada "em um recurso ao infinito" (Sartre 13, p. 13), pois a transcendência mesma do objeto exige que a aparição, para não ser meramente subjetiva, se faça sempre transcender, a ponto de que "um objeto põe por princípio a série de suas aparições como infinitas" (id., ibidem). Ora, seja a ligação das representações, seja o fenômeno husserliano, cuja síntese remete a um X vazio, a um noema irreal ("irreal" porque ele é a unidade de infinitas aparições), nada disso poderá jamais constituir o objeto. O que em Sartre quer dizer: nada disso servirá jamais de fundamento a uma "negação ulterior que cortaria o não eu e o oporia ao eu"; uma tal negação deve ser "dada de início", é ela "o fundamento a priori de toda experiência" (id., ibid., p. 222). Nada, senão uma negação originária, pode separar o "eu" do "não eu". Não há portanto em Sartre uma camada prévia em que as duas instâncias se confundam, se imbriquem, antes de virem a se constituir como distintas. Ao contrário, a diferença começa por ser estipulada, dada de início, como condição mesma para que se possa falar em objeto: "É impossível que eu tenha alguma experiência do objeto, como objeto que eu não sou, antes de constituí-lo como objeto. Mas o que torna, ao contrário, toda experiência possível é um surgimento a priori do objeto para o sujeito, ou, pois o surgimento é um fato original do para si, um surgimento do para si como presença ao objeto que ele não é" (id., ibid., p. 224). É nesse sentido que a negação "é um laço ontológico concreto" (id., ibid., p. 225). 


\section{VI}

Ora, mas isso significa que o objeto, posto apenas como não eu, seja já posto como tal?, que não haja em Sartre nenhuma camada constituinte e que, portanto, de algum modo, ele pague um tributo ao prejuízo dogmático do objetivismo? Não se trata disso, e é aqui que a negação vai aparecer como "produtora". Pois ela será uma negação do ser em si a partir da qual a ordem dos fenômenos será constituída. É a partir dessa negação que será possível a experiência do objeto. Haverá, como contrapartida da negação, uma "afirmação intencional", quer dizer, a partir da negação originária, a afirmação "mundo" vai acontecer ao em si (Sartre 13, p. 269). Reside aqui a camada constituinte ou o aspecto criador da negação. Mas que é criado afinal? A criação, evidentemente, não vai estar do lado do ser, sempre já dado, mas do lado do fenômeno - ou antes, do lado do fenômeno e do lado da consciência, que são termos correlatos. ${ }^{(7)} \mathrm{E}$, se "consciência" é aqui um dos termos, é porque a negação é não apenas negação do ser em si, mas também negação de si mesma. ${ }^{(8)}$ À maneira sartriana: se a negação deve ser um puro não, ela não pode cristalizar-se como ser, ainda que negativo. Uma pura negação deve ser ruptura com uma substancialização que a faria coincidir consigo mesma. Daí por que ela deve ser também negação de si mesma e daí por que haverá "consciência" - ou, se se quiser, múltiplas "dimensões de nadificação", ou múltiplas maneiras de não ser essa coincidência (presença a si, dispersão temporal, reflexão etc.) (id., ibid., p. 182). Haverá "consciência" na medida em que o para si não apenas é como não sendo tal ser, mas também na medida em que ele não é essa negatividade como ser. Só há consciência de si porque a verdadeira negação é negação voltada sobre si mesma - quer dizer, negação pura. Eis aí a insuficiência do cogito cartesiano: seria preciso levar a negação para além da hipótese do Gênio Maligno, até o ponto em que ela se volta sobre si mesma e fundamenta assim um cogito, uma consciência. É assim que o para si é consciência de algo: não apenas porque é negação desse algo, mas também porque, sendo negação voltada sobre si, torna-se presença a si, não coincidência consigo e 
assim consciência (de) si. A consciência, portanto, não tem nenhuma consistência, nem mesmo a de ser negação; daí por que ela é um transcender permanente, um escapamento de si mesma (Sartre 12, p. 220 e 263). ${ }^{(9)}$ Ora, tudo isso supõe que a negação de que aqui se fala não seja do tipo " $\mathrm{X}$ não é Y", "a xícara não é o tinteiro", negação que Sartre denomina "externa", porque ela é um puro laço de exterioridade estabelecido por um terceiro. Neste caso, tal negação "não enriquece nem constitui" os elementos envolvidos (idem 13, p. 223). Na negação de que fala Sartre, ao contrário, um dos elementos - o para si - não é posto de início para depois negar tal ser, indiferentemente. Ela é antes uma negação originária a partir da qual o próprio para si, incriado, vem a se constituir, a se qualificar. Não há originariamente uma substância, um sujeito, que estabeleceria a posteriori um laço negativo com o em si. Ao contrário, o para si se determina a partir dessa negação, e se determina como tal porque a negação se volta sobre si. Por isso, a essa negação, que não remete a um testemunho, já que é negação de si mesma, Sartre denomina interna (id. ibid.). Inteiramente dessubstancializado, o para si não é originariamente nada, senão essa negação pura.

E não se trata apenas, como dissemos, da constituição da consciência, mas também da constituição do "fenômeno". Depois de ter investigado a negação de si, Sartre passa àquela outra, relativa à negação do ser em si. $^{\left({ }^{(10)}\right.}$ A estrutura negativa é uma só, pois se trata de uma negatividade que, enquanto tal, escapa à coincidência consigo mesma e, portanto, é uma negação do ser que é também negação de si; por isso, consciência e fenômeno compõem um único todo. Há aqui, no mesmo ato, uma posição, pela quál o fenômeno é constituído, e uma autoposição, pela qual a consciência é constituída. E, como o ser repousa na indiferença absoluta, "a chave da relação" do para si com o ser deve ser buscada "apenas no para si" (id., ibid., p. 220). ${ }^{(11)}$ Portanto, a afirmação "mundo" só existe para o para si, ela é inteiramente relativa a ele e "desaparece com ele" (id., ibid., p. 269). Ora, segue-se daí que essa afirmação está no para si?, que ela é uma simples modificação subjetiva? De fato, o fenômeno é relativo à consciência, não há um sem a outra, e vice-versa. No entanto, um tal fenômeno não tem o estatuto que tem em Descartes, por exemplo, a aparência sensível, que é subjetiva 
no sentido em que é confinada no sujeito, evento puramente interior por oposição a um exterior da ordem da essência inteligível. Seria ele como a Erscheinung kantiana? Afinal, a Erscheinung é bem mais que uma mera aparência sensível confinada numa subjetividade: ela é dotada de objetividade, relativa a um sujeito, não interior a ele, ela é para um sujeito, não está dentro dele. Entretanto, uma tal revolução copernicana, que faz a objetividade girar em torno do sujeito, tem ainda, para Sartre, uma séria limitação: ela é duplamente relativa, não apenas a um sujeito a quem aparece, mas também a um noumeno "por cima de suas costas" (Sartre 13, p. 12 e 14). É o noumeno, o absoluto, o em si - o que significa dizer que o fenômeno se opõe ao em si (id., ibid., p. 189). Ora, é essa segunda relatividade, assegura Sartre, que já não encontramos em Husserl, e por isso o fenômeno é ali um "relativo-absoluto": "O que ele é, ele o é absolutamente, pois ele se desvela como ele é" (id., ibid., p. 12). A fórmula é paradoxal: "fenômeno em si" ou "relativo-absoluto". Mas é ela mesma que Sartre pretende levar adiante, e é ela que Husserl compromete quando, em desdobramento da revolução copernicana, pretende dotar o sujeito de poderes constituintes, mesmo em relação ao ser do fenômeno. Pois, enfim, é o que termina por acontecer, garante Sartre, quando Husserl reduz o ser à unidade das aparições, ao X idêntico e irreal, correlativo da noese (id., ibid., p. 28). Não há mais aquela segunda relatividade da Erscheinung kantiana, mas é porque o ser deve sair agora da imanência. Eis a maneira pela qual Sartre interpreta Husserl. Resulta daqui, evidentemente, uma diferença em relação a Kant, pois, no caso kantiano, o fenômeno ainda se opõe ao em si. Entretanto, é justamente por conta dessa oposição que a objetividade do fenômeno vai remeter apenas ao sujeito. Ora, mas que pode significar um tal fenômeno, cuja objetividade é posta pelo sujeito? No limite, sua pretensão à objetividade será a medida do idealismo, como se, no final das contas, a balança do idealismo transcendental e do realismo empírico em Kant tendesse a se desequilibrar, pela exigência da objetividade do fenômeno, em favor do idealismo. É o que permite compreender as passagens de Sartre relativas ao "idealismo kantiano", aproximando-o do de Husserl (id., ibid., p. 115), e a afirmação decisiva, a propósito do relativismo kantiano, de que ali, finalmente, o próprio ser, e 
não mais apenas o fenômeno, é relativo ao sujeito (Sartre 13, p. 270). Evidentemente, trata-se aqui de um desdobramento inteiramente orientado pela rejeição inicial da revolução copernicana. Noutras palavras, o que está em questão para Sartre é, em suma, um único ponto: lembrar - embora isso seja dito no contexto de seu debate com Husserl - que "jamais o objetivo pode sair do subjetivo, nem o transcendente da imanência" (id., ibid., p. 28). Daí por que tudo vai se resumir a isso: à necessidade de inverter o procedimento genético, pois a objetividade não pode vir jamais a posteriori, inversão inteiramente comandada pelo problema da objetividade. Por isso, "objetividade" implica aqui um sentido metafísico, não apenas um sentido reduzido - se se quiser, o ôntico reclama o ontológico, o fenômeno reclama o ser -, pois é exatamente esse o ponto em questão no debate com Husserl: a recusa sartriana da redução transcendental implica a afirmação do ser como ponto de partida, o que, evidentemente, acarreta um projeto de filosofia distinto do husserliano. Parte-se do ser, ou antes, parte-se do cogito, mas parte-se dele com a condição de "sair dele" (id., ibid., p. 116), isto é, de pôr, já de início, a relação a uma transcendência. É porque se põe de início o ser, a transcendência, em vez de pretender, inutilmente, arrancá-la do sujeito, que se pode, finalmente, resolver o paradoxo do "fenômeno em si".

\section{VII}

O ser está realmente presente, já de início, e é a partir dele, por negação dele, que um fenômeno pode se descobrir a mim. ${ }^{(12)} \mathrm{O}$ fenômeno, portanto, tem como pressuposto uma negação que distinga o "eu" do "não eu", do que não remete ao "eu". A partir daí, o fenômeno será "alguma coisa que acontece ao em si", resultado de sua negação. Ele será uma "ek-stase passiva" do ser em si, que o deixa "inalterado" e que entretanto "efetua-se nele" (id., ibid., p. 269). Nele, não no para si, pois o para si é ek-stase ativa, ele está fora, no ser, como negação desse ser. É isso que pode ser mostrado se 
Moutinho, L.D.S., discurso (33), 2003: 105-52

se desdobra até o fim essa negação de dupla face, negação do ser dado e negação voltada sobre si - embora visada aqui na perspectiva da constituição do fenômeno.

O para si não é de início presença a isto ou àquilo; é sua presença que faz que haja um "isto" ou um "aquilo", é sua presença que "faz que um isto exista" (Sartre 13, p. 229). O há não é portanto uma determinação interna do ser; é apenas a contraparte da negação. Ora, mas tal negação é também negação de si, pela qual o para si se constitui como dispersão temporal ou ser "diaspórico", isto é, um ser que, coeso, se dispersa contudo em múltiplas dimensões - presença a si, dispersão temporal etc. ${ }^{(13)} \mathrm{O}$ para si é totalidade aberta em transcendência perpétua, pois é continuamente negação voltada sobre si (ou "totalidade destotalizada", como diz Sartre para frisar o aspecto negativo do para si). Daí por que o para si, realizando o isto, enquanto presença a este ser, realiza também todo o ser, isto é, o mundo. Ele realiza o todo enquanto ele próprio é presença a este ser como totalidade aberta em inacabamento perpétuo: "A presença do para si ao ser como totalidade vem de que o para si tem de ser (...) sua própria totalidade como totalidade destotalizada" (id., ibid., p. 229-30). Certamente, essa negação realizante não realiza apenas o isto e o todo, ela realiza também o próprio para si, isto é, o para si também se qualifica a partir dessa negação, pois ele não é dado de início para depois se constituir como negação. Ao contrário, ele se determina pela negação, e na exata medida dela: ele "se faz anunciar", para usar uma expressão recorrente em Sartre (id., ibid., p. 225, 230, 236, 248 etc.), a partir disso que ele realiza e que ele não é, sendo dele negação. Trata-se aqui, evidentemente, de levar até o fim o projeto de tudo extrair da negação. Daí por que, em resumo, Sartre afirme, a propósito desses diversos momentos: "O para si realiza-se como presença realizante a este ser sobre fundo original de uma presença realizante ao todo. Mas reciprocamente a totalidade (...) não pode se desvelar senão em e pelos 'istos' singulares. O que significa que o para si se realiza como presença realizante a todo o ser, enquanto presença realizante aos 'istos' - e aos 'istos' singulares enquanto presença realizante a todo o ser" (id., ibid., p. 229). É essa relação original, assegura Sartre, que está na fonte daquilo que a Gestalttheorie trouxe à luz 
como a relação entre o fundo e a forma (Sartre 13, p. 231). Aqui, no nível ontológico, é o para si que realiza o isto e o mundo e se realiza a si próprio a partir de uma negação do ser que ele não é presentemente.

Assim, não há uma totalidade prévia, um todo já dado, do qual o para si seria negação: o em si, diz acertadamente Juliette Simont, "pode apenas ser o que é, ele não pode ser omnitudo" (Simont 16, p. 47). Não há todo o ser, no qual as determinações já estariam contidas; o todo, diz ela, "resulta da negação" (id., ibid.). No entanto, porque não vê de onde vem a determinação todo, Simont crê que, se o para si "faz do ser um todo", é porque ele é "negação do todo do ser" - e isso na medida em que ele é um "nada puro". Simont incorre, nesse caso, em uma petitio principii: se o todo resulta da negação, não pode haver, originariamente, uma "negação do todo". $\mathrm{O}$ "todo" é já uma determinação, portanto, oriundo da negação, não é ser, diante do qual se põe o nada puro. O para si é presença realizante ao todo na medida em que ele se constitui como totalidade, e ele se constitui como tal na medida em que é negação de si mesmo e instaura, assim, a multiplicidade no seio da unidade. É assim que o para si se transcende para uma totalidade - que é a sua e a do fenômeno, constituindo ambas o que Sartre denomina o "circuito de ipseidade". Em suma, o para si realiza o há, ele faz que haja ser (Sartre 13, p. 228), e, portanto, é em seu há que o ser é relativo ao para si (id., ibid., p. 270), e o para si se realiza igualmente nessa realização do há em uma negação interna (já que não remete a um testemunho) que é o fundamento dessa dupla realização. Aquilo que é realizado, do lado do fenômeno, é o "sentido do ser", a "maneira pela qual o ser se desvela como não sendo o para si" (id., ibid., p. 230). Trata-se aqui de uma maneira de o ser se desvelar que não é ainda, paradoxalmente, nem o desvelamento do próprio ser (que não se fenomeniza jamais), nem uma projeção do para si. Para entendê-lo, é preciso desviar o olhar para o fenômeno e observar, do lado do isto, essa maneira de o ser se desvelar.

$\mathrm{E}$, desse ponto de vista, a negação que o constitui como isto é apenas “ideal”. A razão disso, para Sartre, é que "o ser visado como 'isto' (...) não pode estar fora de si mesmo no todo como estrutura do todo, nem também estar fora de si mesmo no todo para negar de si mesmo sua identidade com 
o todo" (Sartre 13, p. 232). Com efeito, o isto se constituiria como tal se ele pudesse estar fora de si mesmo; mais: se partisse dele a negação pela qual ele se distinguiria do todo. Como sempre, vale o princípio de que a constituição de si tem por fundamento a negação pela qual aquele que nega se qualifica, se determina, negação feita lá fora, junto àquilo que é negado, de tipo interna, isto é, voltada sobre si e, portanto, testemunha de si mesma. Evidentemente, não é o tinteiro que nega de si mesmo que ele seja a mesa, o copo, o cachimbo etc., e portanto não é ele que se constitui como tal. Ele precisaria estar fora, naquilo que nega, "e por isso ele deixaria de ser em si para tornar-se para si" (id., ibid., p. 234). Assim, o isto não se realiza como isto. É o para si que faz que um isto exista. Daí por que, do lado do isto, a negação que o constitui seja "ideal". Ora, mas, se é assim, não se vê em que isso muda a tese "idealista" da constituição. É verdade que, para Sartre, o ser está presente de início, mas resta que a objetividade do fenômeno parece ser aqui inteiramente remetida ao para si - o que, no final das contas, torna incompreensível a negação originária que justamente distingue o "eu" do "não eu”; afinal, se o ser negado está realmente presente, já não se pode incorrer em uma posição como a kantiana. De que adianta a negação originária, a posição do ser, se, logo depois, se quer lançar a objetividade do fenômeno exclusivamente na conta do para si?

É aqui que se revelam os favores que Sartre pretende obter da negação. A idéia nuclear é que há apenas negação na relação do para si ao em si. Aqui é preciso frisar bem que apenas a negação vem do para si ao ser: "Nada, senão a negação, pode vir ao em si pelo para si" (id., ibid., p. 233). Por isso, esse desvelamento não modifica, não altera o isto, não acarreta qualquer tipo de relação real, como uma síntese de todos os istos em totalidade, por exemplo (id., ibid., p. 232). Nada de real (por isso se entenda: já que o ser é dado, nada que passaria a pertencer ao em si) pode advir de uma negação. Daí por que não apenas não há constituição de ser, em sentido metafísico, como a própria determinação fenomênica, justamente porque ela resulta de uma negação, não de uma constituição, não é nada de real. Assim, a determinação do isto diante do todo permanece exterior ao isto, não o atingindo por dentro, não o alterando em uma vírgula. Dizer que a determinação 
remete ao para si é dizer que ela remete a uma simples negação, não a um princípio constitutivo. Mas então, por isso mesmo, uma tal determinação não remete apenas ao para si, mas também ao em si negado. Quer dizer, só se pode estabelecer o estatuto da determinação se se levar em conta que o ser negado é ele próprio dado sem relação: "O ser é isolado em seu ser e não mantém nenhuma relação com o que não é ele (...) Ele é plena positividade. Ele não conhece a alteridade: ele não se põe jamais como outro de um outro ser; ele não pode sustentar nenhuma relação com o outro. Ele é ele mesmo indefinidamente e se esgota em sê-lo" (Sartre 13, p. 33-4). É finalmente por isso que se pode afirmar que, dado que a negação interna realizante e relacionante é negação de um ser inteiramente positivo e sem relação, toda determinação que ela pode estabelecer, vista do lado de lá, será sempre externa ao ser. A negação pela qual o isto se estabelece diante do todo é de tipo externa e correlata da negação interna que parte do para si: "A negação constitutiva do isto é uma negação do tipo externa, a relação do isto ao todo é uma relação de exterioridade. Assim, vemos aparecer a determinação como negação externa correlativa da negação interna, radical e ekstática que eu sou" (id., ibid., p. 232). Deixemos para explicitar mais detalhadamente a idéia da correlação um pouco adiante. Por ora, observemos que, uma vez remetidas a esse "duplo fundamento"(14) - o para si, que estabelece relação, e o em si, que é sem relação -, as determinações fenomênicas podem, a um só tempo, remeter ao para si e ainda serem exteriores pois advêm da negação de um ser que é presente e dado, não são positividades constituídas pelo para si - e serem exteriores sem seres reais - pois advêm de uma negação que, por ser negação, nada acrescenta ao ser, em nada o modifica, sendo apenas maneiras pelas quais o para si realiza o há (id.,ibid., p. 234). ${ }^{(15)}$ Tais determinações nada acrescentam ao ser, diz Sartre a propósito da totalidade, por exemplo (a totalidade nem mesmo alcança o ser, "não mais que o fato de contar duas xícaras sobre a mesa alcança qualquer uma das xícaras em sua existência ou em sua natureza" (id., ibid., p. 230), e, mais geralmente, a propósito do que Husserl denomina as categorias (unidade-multiplicidade-relação do todo a parte, mais e menos, em torno de, ao lado de, na seqüência de, primeiro-segundo etc., um-dois-três etc.) 
(Sartre 13, p. 241; Husserl 4, p. 106-7). Trata-se aqui, sempre, de "mesclas [barrages] ideais das coisas, que as deixam inteiramente intactas, sem enriquecê-las nem empobrecê-las em uma vírgula", "mesclas" que estabelecem relações entre coisas "que não têm nenhuma relação" (Sartre 13, p. 241). Tais "mesclas" não são nem fantasmas subjetivos, nem objetividades reais; elas são exteriores em sentido inédito, seja ao para si, seja ao em si: são determinações que recusam "todos os suportes", são "nada" (id., ibid., p. 235). Assim, é uma negação que subjaz à determinação "tinteiro", mas não uma negação pela qual o tinteiro se distingue do todo, negação interna; trata-se antes de uma negação ideal: "Toda determinação que não pertence ao ser que tem de ser suas próprias determinações é negação ideal" (id., ibid., p. 234). Noutras palavras, "é porque o tinteiro não é a mesa - nem o cachimbo, nem o copo, etc. - que podemos apreendê-lo como tinteiro. E, entretanto, se eu digo: o tinteiro não é a mesa, eu não penso nada. Assim, a determinação é um nada que não pertence, a título de estrutura interna, nem à coisa, nem à consciência" (id., ibid., p. 235). É um nada "unselbständig ", que, no entanto, não se relaciona a nenhuma substância (id., ibid.), "substancializado" (id., ibid., p. 269) ele mesmo, permanecendo "no ar" (id., ibid., p. 235), como condição de realização do há (id., ibid., p. 270).

\section{VIII}

E não se trata aqui, apenas, do que classicamente remete ao "entendimento", mas também do que remete à "sensibilidade". Assim, por exemplo, as "formas da sensibilidade", o espaço e o tempo. Vejamos aqui, muito brevemente, o caso do tempo e depois o do sensível. O tempo de que se trata é o "tempo do mundo", o tempo objetivo - não a temporalidade como "modo de ser unitário de um ser que é perpetuamente à distância de si para si” (id., ibid., p. 255). Nesse sentido, se o isto se desvela temporalmente não será porque "ele se refrataria através de uma forma a priori do sentido interno, 
mas porque ele se desvela a um desvelamento cujo ser mesmo é temporalização" (Sartre 13, p. 255). É por isso que, desde que eu percebo esse tinteiro, eu já o percebo em suas três dimensões temporais - mas isso não significa conferir-lhe uma duração. Antes disso, o para si dispõe sua temporalidade ao longo do em si "como ao longo de um muro imenso e monótono do qual ele não vê o termo" (id., ibid.). Daí por que vai surgir aqui uma ambigüidade análoga à do mundo, que se desvela como "totalidade sintética"já que é desvelado pelo para si, que é totalidade - e como "coleção puramente aditiva de todos os "istos"” - já que há uma "limitação ideal" a essa síntese, limitação advinda da relação que o constitui, de tipo externa (id., ibid., p. 232-3). No caso do tempo, trata-se da temporalidade com que é desvelado o em si e da a-temporalidade do ser: o isto aparece originalmente como temporal, pois ele é desvelado por um para si temporal, como antes o ser aparecia como totalidade porque era desvelado por um ser que tinha de ser sua própria totalidade; mas tal ser se recusa a ser sua própria temporalidade, como antes a negação constitutiva do isto era externa, não algo que o atingisse por dentro. Daí por que, segundo Sartre, o ser apenas reflete o tempo, e esse reflexo, ou "fantasma", é o tempo objetivo: "A temporalidade, enquanto é apreendida objetivamente, é um puro fantasma, pois ela não se dá como temporalidade do para si, nem também como temporalidade que 0 em si tem de ser" (id., ibid., p. 256). Nem do para si, nem do em si, o tempo tem aqui uma "natureza contraditória", cujo duplo fundamento remete ao para si e ao em si (id., ibid., p. 257), mas que não é nem de um, nem de outro. A temporalidade do para si torna-se "fantasma" porque o ser é sem tempo, na mesma medida em que a relação ek-stática interna torna-se relação objetiva de exterioridade porque o ser é sem relação. ${ }^{(16)}$ A coesão do tempo do mundo é um "puro fantasma", apenas "reflexo do projeto ek-stático do para si” (id., ibid., p. 267) - assim, ele é também um nada, um “jogo iridescente [chatoiement] de nada na superfície de um ser rigorosamente atemporal" (id., ibid., p. 268).

Quanto ao sensível, pode-se perscrutar um pouco mais esse modelo e perguntar o que resta afinal não mais das formas da sensibilidade, mas do próprio sensível - da cor desse objeto, por exemplo, que não parece poder 
ser reduzida a uma relação, a um nada. E, de fato, a cor é um ser, não um nada, e, por isso, ao tratar desse tema, Sartre retoma a discussão acerca do noema e da hýle, recusando a subjetivização da qualidade: "O amarelo desse limão não é um modo subjetivo de apreensão do limão: ele é o limão" (Sartre 13, p. 235). As qualidades sensíveis do objeto se interpenetram, diz ele, justamente como Cézanne o teria mostrado: "A fluidez, a tepidez, a cor azulada, a mobilidade ondulosa da água da piscina são dadas de uma só vez, umas através das outras" (id., ibid., p. 236). Por isso, a qualidade do ser é "todo o ser", e é essa interpenetração que se chama o isto. Como a qualidade é ser, a sua apreensão remete àquela negação originária que faz que haja ser, negação pela qual o para si se faz anunciar o que ele não é: "Perceber o vermelho como cor desse caderno é se refletir a si mesmo como negação interna desta qualidade" (id., ibid.). A qualidade é então o ser - ou melhor, todo o ser - se desvelando "nos limites do "há", (id., ibid.), como aquilo que nós não somos, cujo modo de ser é radicalmente diferente do modo de ser do para si. Ora, mas sabemos também que, ao realizar o isto, o para si realiza também o todo e que não há um sem o outro, de modo que a cor é necessariamente lançada em uma teia de relações. Ora, acontece que a relação que une o isto e o todo é puramente externa, correlata da negação interna pela qual o para si os realiza. Daí por que as aparições do isto sobre o todo serão tão diversas quão diversas serão "as maneiras pelas quais a liberdade do para si pode realizar a indiferença do ser" (id., ibid., p. 241; grifo nosso). Há aqui uma correlação: livremente o para si constitui seu ser e desvela o ser de uma certa maneira, de modo que, à liberdade do para si, que constitui espontaneamente seu ser, "corresponde um desvelamento total do ser "por um perfil"” (id., ibid., p. 237). Tudo se passa da seguinte maneira: há um ser dado de início, contingente (id., ibid., p. 34). Pensemos aqui na cor, que, como ser, independe inteiramente de mim: eu não posso fazer que essa casca não seja verde. Mas a realização do há acarreta uma necessidade: não haverá jamais isto sem todo, forma sem fundo: "A estrutura formal desta relação da forma ao fundo é (...) necessária. (...) a existência de um campo visual ou tátil ou auditivo é uma necessidade: o silêncio, por exemplo, é o campo sonoro de sons indiferenciados sobre o qual se destaca o som parti- 
cular que nós visamos" (Sartre 13, p. 380). Entretanto, se tal estrutura é necessária, será contingente a ligação de um tal isto ao fundo, existindo para ele uma infinidade de maneiras de aparecer: "É necessário que o livro me apareça à direita ou à esquerda da mesa. Mas é contingente que ele me apareça precisamente à esquerda, e, enfim, eu sou livre para olhar o livro sobre a mesa ou a mesa sustentando o livro" (id., ibid.). Há aqui, portanto, uma escolha, embora uma escolha que se opera "a partir de uma distribuição original dos istos" (id., ibid.). Assim, se é verdade que a cor independe de mim, é verdade também que ela é apreendida, forçosamente, em um conjunto, e que, por fim, seu desvelamento aparece "como uma gratuidade de fato apreendida através de uma liberdade" (id., ibid., p. 238). Por que gratuidade? Porque, se é verdade que essa casca me seja dada como verde (contingência), se é verdade ainda que ela me aparece em um campo visual (necessidade), é verdade também, por outro lado, que a maneira pela qual ela me é desvelada é contingente. Onde pode haver aí contingência? Sou eu, diz Sartre, "que faço que eu apreenda [a casca verde] como verde-rugosa ou como rugosidade-verde" (id., ibid.). Eis aqui a gratuidade: a apreensão do verde remete a uma negação interna pela qual o para si o realiza como forma e a rugosidade como fundo; nesse sentido, tal relação é "escolhida" (id., ibid., p. 380), portanto, gratuita, correlata da "liberdade do para si", ainda que a ligação entre a forma e o fundo seja necessária. É verdade ainda que há uma diferença entre essa relação entre a forma e o fundo e aquela pela qual se apreende um isto no mundo. É que, ali, a forma e o fundo (a cor e a rugosidade da casca) se interpenetram: a apreensão da casca como verde vai desvelar sua "luminosidade-rugosidade" "como fundo interno indiferenciado", de tal modo que a forma seja "inteiramente penetrada pelo fundo" (id., ibid., p. 238; grifo nosso). Há aqui tanta gratuidade quanto na apreensão do isto no mundo - do livro ou da mesa como forma. Acontece que, neste caso, o fundo é externo e, naquele outro, interno - lá, o horizonte é o mundo; aqui, o horizonte são as demais qualidades que se interpenetram e penetram a forma. É por isso que, segundo Sartre, "a qualidade não é mais que o ser do isto quando ele é considerado fora de toda relação externa com o mundo ou com os outros istos" (id., ibid., p. 235; "fora" grifado por nós), 
quando, enfim, o para si realiza o isto mergulhando em seu horizonte interno. Mas, seja apreendendo a cor - o isto e o seu horizonte interno -, seja apreendendo o isto no mundo - o isto e o seu horizonte externo -, em toda parte o ser é desvelado segundo uma maneira, e é essa maneira a condição de realização do há. Ela não é nada, ela nada acrescenta ao ser - a apreensão da qualidade, diz Sartre, "nada acrescenta ao ser, senão o fato de que há ser como isto" (Sartre 13, p. 236). Tal maneira remete a um ato gratuito do para si, pelo qual ele se realiza e realiza o há; é por uma negação interna do em si que o para si realiza o há: a afirmação "mundo" acontece ao em si pelo para si. Mas nem por isso o mundo é uma projeção do para si. Ao idealista, deve-se conceder que não há mundo senão pelo para si, mas isso não implica dizer que o mundo vem ao ser pelo para si; trata-se antes do inverso: é o ser que vem ao mundo pelo para si. Daí a inversão da posição idealista, já que o ser está realmente presente ao para si (id., ibid., p. 268-9). Ora, mas o mundo não é outro que o em si? Ao realista, deve-se conceder que o mundo é o próprio ser, que o fenômeno é em si, que ele é "relativo-absoluto", pois o para si nada acrescenta ao em si, em nada modifica o ser: espacialidade, temporalidade, quantidade, mundanidade etc. são apenas "nadas substancializados" através dos quais o ser se revela (id., ibid., p. 269) - o próprio ser, não uma deformação subjetiva, não um representante dele. Tudo é dado, diz Sartre, tudo está presente a mim sem distância; neste sentido, não há nada fora do que eu vejo: o ser está em toda parte. Mas esse ser que me investe e do qual nada (rien) me separa, esse nada (rien), justamente porque é nada (néant, o nada substancializado), "é insuperável”: o para si é "presença imediata" ao ser, mas, porque é separado dele por nada, é separado dele em uma "distância infinita". Por isso, não posso apreender o ser, embora ele esteja em toda parte. Sou remetido a mim mesmo, se pretendo apreender o absoluto: eu me reencontro em toda parte entre mim e o ser. E, inversamente, se pretendo tornar essa apreensão subjetiva, sou remetido de volta ao absoluto, já que o ser está em toda parte e nada o separa de mim. 


\section{IX}

Eis aqui, enfim, a camada "constituída" que resulta da negação, da negação produtora. E como se trata de negação, não de uma constituição positiva, tudo o que ela produz é nada, ou, como diz Sartre, apenas "maneiras de ser"; a negação não cria ser, não produz ser, ela nada acrescenta ao ser, ela apenas realiza, por esses nadas substancializados, o há. E, se é assim, é ainda porque o ser negado é um ser em si realmente presente, em face do qual as determinações não têm realidade: o em si não é minimamente afetado pela negação, ele continua sendo o que é, de modo que a negação constitui apenas um nada que não é nem mesmo uma película a me ocultar o ser. É por isso que o fenômeno é relativo, visto que remete ao para si, e absoluto, já que ele nada me oculta. Ora, se voltarmos a Descartes e ao negativo que Sartre ali vislumbra - negativo que prefigura Hegel -, somos forçados a apontar uma extensão do negativo aparentemente desconhecida pela metafísica clássica. De fato, ao fazer o elogio de Descartes, Sartre destacava ali apenas um aspecto do negativo, aquele que o faz confundir com a liberdade. A possibilidade para a realidade humana de secretar um nada que a isola, diz Sartre, foi o que Descartes denominou liberdade (Sartre 13, p. 61). É verdade que mesmo esse poder de escapar, de se pôr fora de alcance, de se retirar, ou, mais geralmente, de simplesmente dizer "não", não traduzia ainda a autonomia visada por Sartre. Por mais que ele exprima a primazia da vontade, mesmo em face do verdadeiro, ele não se converte ainda, como vimos, em uma produção: ele nada produz, ele não é criador. De modo que, se é verdade que Descartes, como também quer Merleau-Ponty, "entreviu em um clarão a possibilidade de um pensamento negativo", é verdade igualmente que, nele, "a idéia do infinito precede a do finito, e todo pensamento negativo é uma sombra nesta luz" (Merleau-Ponty 10, p. 181). Descartes não levou até o fim a idéia de autonomia e, com ela, a idéia de criação. Ora, mas a extensão do negativo em Sartre não se reduz à autonomia do sujeito. Era essa extensão que "A liberdade cartesiana" não desenvolvia, já que se ocupava apenas em mostrar os desdobramentos do conceito de liberdade, 
Moutinho, L.D.S., discurso (33), 2003: 105-52

entravados em Descartes, acredita Sartre, por postulados dogmáticos e sublimados em Deus. Coube a $O$ ser e o nada apontar essa extensão, mostrando que o negativo habita agora a realidade em sua intra-estrutura, que ele se converte agora em "condição de positividade" - idéia estranha aos clássicos do XVII, que convertiam o negativo, em face do infinito, em mera sombra. Não foram os clássicos, foi Kant o primeiro a vislumbrar o papel posicional da negação: "Existe uma quantidade infinita de realidades (...) que são habitadas pela negação em sua intra-estrutura, como por uma condição necessária de sua existência (...) Kant tinha entrevisto seu alcance quando falou dos conceitos limitativos ( $i$-mortalidade da alma), tipos de sínteses entre o negativo e o positivo, em que a negação é condição de positividade" (Sartre 13, p. 57). De fato, ao que parece a negação torna-se em Kant posicional, encontramos nele, como nos assegura Lebrun, a idéia de que a sombra é "inseparável daquilo que ela ensombrece", e nisso, certamente, "Kant difere dos clássicos" (Lebrun 7, p. 261). A negação é posicional, isto é, ela torna-se uma "qualificação para o ser finito" (id., ibid., p. 259): ainda que a realidade enquanto tal seja algo de positivo, a negação adquire o poder de limitar e determinar o grau de realidade, a sua finidade. Lebrun cita Considerações sobre o otimismo (1759): "Se [as realidades] devessem diferir umas das outras enquanto realidades, precisaria haver em cada uma algo de positivo que não estaria na outra: pensaríamos então em algo de negativo pelo qual ela se distinguiria da outra (...) Portanto, uma realidade e uma realidade só se distinguem uma da outra pelas negações, as ausências, os limites que afetam uma das duas - não em relação à sua natureza [qualitate], mas à sua grandeza [gradu]" (id., ibid., p. 259-60; idem 8, p. 274). A negação, certamente, não é uma qualidade; antes disso, ela tem o poder de qualificar, de pôr "pelo próprio fato de excluir" (idem 7, p. 259), de modo que os seres do mundo tornam-se "indissoluvelmente reais e negativos": "A 'parte', malgrado o que ela comporta de positivo, não pode nunca ser despojada de sua "parcialidade"” (id., ibid., p. 261). Daí por que a carência não se reduz mais, como acontecia entre os clássicos, a uma mera fantasia, mas se torna, para nós, "a única maneira de distinguir a coisa" (id., ibid., p. 260). Ora, que isso pode significar?, que significa dizer que a nega- 
ção não é mais uma simples sombra, mas aquilo que dá relevo à realidade? A realidade suprema já não pode ser mais "um englobante 'quod comprehendat omnia", (Lebrun 7, p. 256): os seres pertencem à realidade total, mas, enquanto determinados, têm "consistência suficiente para que não possam ser reabsorvidos no todo" (id., ibid., p. 260). Surge aqui uma "ruptura entre a Realität em si e a Realität finita e afetada por negações" (id., ibid., p. 264), ou, se se quiser, a um só tempo a negação supõe a realidade total e o ser determinado é posto fora dela (id., ibid., p. 265). É por isso que a prioridade lógica suposta pela negação não se traduz em uma prioridade metafísica. Mas, se é assim, então o negativo não parece tanto prefigurar o hegelianismo, mas indicar outra coisa, apontada por Lebrun: uma "ruptura definitiva entre o finito e o infinito" (id., ibid., p. 267).

E, com efeito, no prefácio ao ensaio sobre as grandezas negativas, de 1763, Kant afirma: “As grandezas negativas não são negações de grandezas, como deixou supor a analogia da expressão, mas algo em si mesmo verdadeiramente positivo, que é simplesmente oposto ao outro" (id., ibid., p. 266; Kant 6, p. 16). ${ }^{(17)}$ Por negativo, não se deve entender um negativo-em-si (o que acarretaria uma oposição por contraditoriedade), mas a simples oposição entre duas realidades positivas (o que não acarreta contradição). A oposição é dupla, diz Kant: "Ou lógica, mediante a contradição, ou real, isto é, sem contradição" (id., ibid., p. 19). No primeiro caso, a conseqüência é nada (nihil negativum irrepraesentabile) (o mesmo corpo que está em movimento e não está em movimento ao mesmo tempo). No segundo, a conseqüência é algo (nihil privativum, repraesentabile) - mas então o que se opõe são duas determinações de mesma natureza, contrárias, não contraditórias. Assim, diz Kant, "a força motriz de um corpo que se dirige a uma região bem como um esforço igual do mesmo corpo em uma direção oposta não se contradizem um ao outro e, como predicados, são possíveis ao mesmo tempo em um corpo" (id., iḅid., p. 19-20). O repouso é aqui a conseqüência, e ele é algo: eu posso pensar a não-existência de um movimento, mas é impensável que ele seja e não seja ao mesmo tempo. Um navio que vem de Portugal ao Brasil perfaz certas milhas com o vento do leste e certas outras com o vento do oeste. Se marcarmos com um sinal + as primeiras e com um sinal- 
Moutinho, L.D.S., discurso (33), 2003: 105-52

as segundas, diremos que ao final de sete dias a rota feita em direção a oeste será: $+12+7-3-5+8=19$ milhas. Há oposição apenas, diz Kant, entre as grandezas precedidas pelos sinais + e - , já que, reunidas, elas se suprimem reciprocamente. Daí por que a grandeza será negativa apenas enquanto estiver ligada a outra grandeza por essa relação de oposição, fazendo desaparecer na outra uma grandeza igual a ela mesma. O movimento para o Oriente é tão positivo quanto o movimento para o Ocidente, não há oposição quando reúno grandezas precedidas por sinal idêntico, por exemplo, pelo sinal -; nesse caso, porque reúno grandezas de mesma espécie, tenho um aumento $(-3-5=-8)$, não uma oposição. É só quando se referem ao mesmo navio, opondo-se, que as grandezas opostas são negativas umas das outras. O negativo tem aqui, portanto, apenas um caráter convencional, não é um negativo-em-si (Lebrun 8, p. 284): "A grandeza alguma, não se pode denominar absolutamente negativa, mas se tem de dizer que +a e -a são, cada uma, a grandeza negativa da outra (...) essa denominação não indica uma espécie particular de objetos quanto à sua natureza intrínseca (...) como toda essa denominação sempre indica apenas a relação de certas coisas entre si, sem a qual esse conceito cessa de imediato, então seria sem sentido pensar em um gênero especial de coisas e denominá-las coisas negativas (...) no entanto, para dar a conhecer ao mesmo tempo nas expressões que um dos opostos não é o contraditório do outro e que, se este é algo de positivo, aquele não é uma mera negação sua, mas lhe é oposto como algo de afirmativo, diremos, seguindo o método dos matemáticos, que a morte [das Untergehen] é um nascimento [Aufgehen] negativo" (Kant 6, p. 23-4). A morte está em "oposição real" com a vida. Acontece o mesmo com o desprazer, tomado então como um "prazer negativo": o desprazer não é mera ausência (absentia) de prazer, aquilo que não requer princípio positivo; antes disso, ele é algo em si mesmo positivo que se opõe em sentido real ao prazer (id., ibid., p. 30). Não é mera ausência, mas privação (privatio), que acarreta, por oposição, supressão de prazer; o zero dessa oposição é o equilíbrio (aequilibrium), não uma simples indiferença (indifferentia), o que corresponderia a uma ausência de ambos os princípios. 
De maneira análoga, é um mal por ausência (mala defectus) não fazer caridade ao necessitado, e um mal por privação (mala privationis) roubá-lo, extorquir-lhe: tomar, nesse caso, é um dar negativo (Kant 6, p. 33), ele supõe um princípio positivo de supressão do bem, mais que uma simples ausência do bem. Para suprimir um pensamento cheio de rancor, é necessário uma atividade, quem quer retomar o ar sério deve esforçar-se por apagar a representação que excita ao riso (id., ibid., p. 43). Acontece o mesmo com as paixões: o triunfo sobre elas requer uma atividade a elas oposta; e essa atividade, diz Kant, está dissimulada nas "profundezas" (Tiefen) de nosso espírito, "não a observamos em seu exercício", "dela não temos consciência" (id., ibid., p. 43-4). Não há diferença, no que concerne à supressão de alguma coisa, entre o que ocorre na "natureza espiritual" e no "mundo corporal": em ambos os casos, é necessária uma oposição real; um pensamento da alma, por exemplo, "não pode deixar de existir sem uma força verdadeiramente ativa do mesmo sujeito pensante". A diferença é que o estado da matéria só pode ser modificado por causas exteriores e o do espírito, por uma causa interior - interior, mas que escapa à consciência (id., ibid., p. 44). Não há menos atividade no espírito quando se crê que ele está "espiritualmente inativo" do que, ao contrário, quando "alguns graus dessa atividade aparecem à consciência" (id., ibid., p. 55).

Ora, certamente, o negativo passa a ter aqui um "valor de realidade" (Lebrun 7, p. 266) - ou, como diz Sartre, o negativo passa agora a habitar a realidade em sua intra-estrutura -, mas o que é característico desse "conceito antidogmático" de oposição real é que o negativo só aparece "na interseção de realidades positivas" (id., ibid., p. 272). Por isso, diz Lebrun, não é tanto o negativo que é reabilitado, é antes "a positividade do ser mundano que é posta em questão" (id., ibid.): trata-se menos da positividade do negativo do que do reconhecimento de que, na Wirklichkeit, há oposições efetivas que engendram privações efetivas (id., ibid., p. 271). Daí por que o axioma parmenídico ainda vale para Kant. Reconhecer, diferentemente do "dogmatismo", que dois positivos podem excluir-se não é ainda pôr em questão aquele axioma: "A realidade é algo, a negação não é nada" (id., ibid., p. 266). É que, se há de um lado uma oposição real, resta que, de ou- 
tro, justamente porque cada um dos termos pode representar o papel tanto do "positivo" quanto do "negativo", não há o "positivo-em-si" nem o "negativo-em-si": "Kant confessa: os signos + e -, sendo desprovidos de toda significação intrínseca, perdem seu interesse quando não são mais empregados em uma relação de oposição (...) o 'positivo' e o 'negativo' não são neles mesmos diferentes" (Lebrun 8, p. 290). Trata-se então de reconhecer, ao contrário da metafísica clássica, que o resultado da oposição real (por exemplo, o repouso) é algo, que ele não é um nada, um mero produto da imaginação. Mas resta que essa oposição supõe a positividade do ser.

Ora, ao que parece, era isso que encontrávamos em Sartre quando ele nos mostrava que o negativo habita a realidade em sua intra-estrutura. Pois, de fato, tratava-se ali não de um negativo em si, mas de uma negação que Sartre denominava "ideal", "externa" (Sartre 13, p. 232), negação que supõe o ser positivo já dado e não o atinge por dentro. E ela é igualmente posicional, já que subjaz à determinação do objeto: é porque o tinteiro não é a mesa, nem o cachimbo, nem o copo, que o apreendemos como tinteiro. Também aqui, portanto, trata-se de mostrar que o objeto, para nós, é posto a partir do negativo, mas esse negativo supõe igualmente o positivo, o ser dado. Assim, trata-se, também aqui, menos de reconhecer a positividade do negativo do que sua condição posicional posterior à afirmação do ser. Ora, mas então, a partir desse reconhecimento, um problema análogo se põe a Sartre e a Kant, e que Lebrun aponta citando um parágrafo de $O$ ser $e$ o nada: trata-se do momento em que, depois de reconhecer o caráter intramundano do nada e apontar que o ser, como plena positividade, não o contém como uma de suas estruturas, Sartre se pergunta "de onde vem o nada?" (Lebrun 7, p. 267 e 730; Sartre 13, p. 58). Ou ainda: já que o axioma parmenídico não está em questão e portanto o nada não é, "qual o estatuto dessa oposição que é contudo um conflito e do qual é preciso reconhecer a presença no mundo?" (Lebrun 7, p. 267).

Em Kant, como vimos, só há negatividade quando uma grandeza é ligada a outra por uma relação de oposição, isto é, quando há ali uma relação de oposição real. É verdade que o negativo só aparece na interseção de realidades positivas, mas é verdade também que há ali uma interseção, isto é, 
uma oposição efetiva. Encontramos no ser finito uma relação "seguramente incompatível com o Ser infinito" - daí, finalmente, o interesse kantiano em "introduzir na filosofia o conceito de grandeza negativa". Menos que prefigurar o hegelianismo, conclui Lebrun, tal grandeza "torna possível a ruptura definitiva entre o finito e o infinito" (Lebrun 7, p. 267); é essa clivagem, "mais profunda do que algum dia foi a do criado e do Criador" (id., ibid., p. 265), que está em questão para Kant. Em Sartre, ao contrário, a validade do axioma parmenídico não vai ao ponto de reconhecer uma oposição efetiva, de modo que a negação posicional não advém de uma relação real; ela não é mais que a expressão idealizada da maneira pela qual o objeto aparece a um sujeito, sem exprimir nenhuma relação real, nenhum conflito, nenhuma oposição entre os seres. Daí por que, se é verdade, por um lado, que o tinteiro não é a mesa, é verdade também, por outro lado, que, ao dizer isso, eu não penso nada (Sartre 13, p. 235). Esse nada, diz Sartre, permanece no ar, ele não remete a uma relação real. Tem razão Lebrun em, distinguindo Kant do dogmatismo pelo conceito de oposição real, pôr Sartre ao lado do dogmatismo, pois dizer que o tinteiro não é a mesa, nem o cachimbo, nem o copo, assemelha-se antes a Malebranche quando falava dos "nadas": minha mão, dizia ele, não é minha cabeça, nem minha cadeira, nem meu quarto... Ela inclui uma "infinidade de nadas, os nadas de tudo aquilo que ela não é” (Lebrun 7, p. 265; idem 8, p. 278). De tudo aquilo que ela não é - ou seja, o não-ser exprime aqui uma alteridade indefinida, um Outro em geral, indiferente ao que nega, não um Outro determinado, que se the oponha como seu Outro. É comparada a todas as outras que essa coisa nãoé assim, nem assim... O nada de Sartre, que permanece "no ar", é desta natureza, é como o da "fillosofia clássica", em que se pode "falar do negativo sem nunca lhe conceder presença, citá-lo sem fazê-lo aparecer" (id., ibid.). Em Kant, o não-ser não é mais esse Outro em geral, indefinido; ao contrário, ele é "como a resultante de um conflito entre duas realidades determinadas" - positivas, certamente, mas em conflito real (id., ibid., p. 283). 


\section{$\mathrm{X}$}

Ora, mas aqui é preciso lembrar que esse nada intramundano de Sartre, que tanto o aproxima do dogmatismo, é apenas um correlato, que ele remete a um duplo fundamento - de um lado, a um ser plenamente positivo, de outro, a um negativo mais originário ainda. Se o leitor sartriano se levanta contra a aproximação feita por Lebrun, é porque ele crê encontrar em Sartre uma outra compreensão do negativo, escamoteada por essa aproximação. Em Sartre, diz o leitor, há um nada originário, um nada em "estado puro" - não apenas aquele nada intramundano - e que já não vai ser pensado, como em Kant, a partir do positivo dado. É por conta desse negativo que, em Sartre, "a fórmula parmenidiana [vai tornar-se] radicalmente diferente de suas interpretações anteriores", a ponto de tornar "quase vã a aproximação operada por G. Lebrun entre a concepção sartriana e a concepção dogmática do nada" (Simont 16, p. 44). De fato, o leitor sartriano tem razão em apontar um outro aspecto do negativo ignorado pela aproximação de Lebrun. Mas, no final das contas, essa lembrança afastará Sartre, de fato, do dogmatismo?, será que, no final das contas, o essencial não permanece, apesar desse nada puro?

Aqui, vale lembrar que depois de apresentar a alteridade tal como a entende o "pensamento clássico" (sobretudo em Espinosa, em que "seu funcionamento aparece com o máximo de clareza") (Lebrun 8, p. 272), Lebrun passa a Kant e mostra que há ali uma oposição efetiva ignorada no XVII, e é essa oposição que faz surgir uma nova figura do negativo. Entretanto, é verdade também que essa nova figura não acarreta o reconhecimento do negativo em si e da contradição: o que ali se opõe são contrários igualmente positivos. Daí por que Lebrun procure atenuar, em face de Hegel, o alcance inovador da Grandeza negativa (id., ibid., p. 283). Ora, se nos servirmos desse mapeamento do conceito de negativo, seria preciso dizer que o nada sartriano, o nada em "estado puro", não é uma mera sombra do positivo, seja inerente a ele, como em Kant, ou sombra que se dissipa com a luz, como no dogmatismo. O "nada puro" é de outra ordem, de tal modo que o axioma 
parmenídico tem aqui um sentido inédito. Ele é o nada efetivo, em relação de contradição com o ser, a tal ponto que mesmo o negativo hegeliano vai aparecer ainda insuficiente: não há ali, crê Sartre, uma verdadeira contradição. Quando, ainda no primeiro momento da Ciência da lógica, Hegel apresenta o ser como pura indeterminação e vazio, de tal modo que nada se pode apreender nele, o que ele aí faz, diz Sartre, é introduzir implicitamente a negação na sua definição de ser; é por isso que ele pode dizer que o ser puro é também nada e "fazer passar" o ser no nada. Mas negar do ser toda determinação e todo conteúdo exige ao menos a afirmação de que o ser é: "Assim, que se negue do ser tudo o que se queira, não se poderia fazer que ele não seja, pelo fato mesmo de que se nega que ele seja isto ou aquilo" (Sartre 13, p. 50). O ser resiste como "plenitude absoluta e inteira positividade", e a negação aparece, por sua vez, como incapaz de atingir seu núcleo. Tudo se passa como se Hegel, tendo já introduzido o nada no ser na forma da indeterminação, não fizesse senão retirá-lo depois, como o prestidigitador que só retira o coelho da cartola porque antes, sub-repticiamente, o introduziu nela (Simont 16, p. 34-5). O que daí resulta, no entanto, é uma simples relação de contrariedade, não mais de contradição, pois, nesse caso, justamente por se ter introduzido o nada no ser, esse se torna como aquele, isto é, ambos se tornam negativos, ou o inverso, e ambos se tornam positivos. Daí por que se trata aqui de uma simples contrariedade, pois os termos são ou igualmente positivos, ou igualmente negativos. Supõe-se, no final das contas, uma "contemporaneidade lógica" entre os termos, uma "simultaneidade" (Sartre 13, p. 50). A verdadeira contradição, por sua vez, acredita Sartre, exige bem mais do que isso: ela exige que os contraditórios não "passem" um no outro, de modo que a exclusividade seja definitiva. O ser é "plena positividade" (id., ibid., p. 33), e o não ser é um puro não ser - tão exclusivos um do outro, tão purificados, que não há mediação possível. Pode-se esvaziar o ser de toda determinação possível, de tudo quanto se queira - não, contudo, de sua identidade consigo mesmo. ${ }^{(18)}$ Assim, o ser não "passa" no nada. E o não ser será seu contraditório, não seu contrário, se ele, por sua vez, se mantiver como o negativo puro, como verdadeira negação do ser. Daí por que há uma "posterioridade lógica do nada sobre o ser" 
(Sartre 13, p. 50): o ser é posto de início e depois negado, o não ser aparecendo como seu contraditório, como negação dele, sem "passagem" de um no outro. É disso, assegura Sartre, que Hegel se esquece, e, se não se quer fazer mágica, é preciso retomar o axioma de Parmênides, "contra Hegel", e dizer, ainda uma vez, "o ser é e o nada não é" (id., ibid., p. 51).

Assim, muito além do dogmatismo, mas também de Kant, Sartre retoma a contradição. Agora, porém, em um sentido que ele pretende ainda mais radical que o de Hegel, já que ali a contradição era escamoteada, mas isso, por sua vez, retrucaria um hegeliano, a um preço bem alto: a exclusividade entre ser e nada é tão definitiva, que já não há superação, há uma tal pureza entre ser e nada, que eles já não "passam” um no outro, e assim não há síntese. Eis o que significa uma pura contradição, e, por isso, se, de um lado, diria o hegeliano, é preciso recusar o princípio da filosofia do Entendimento de que nada se contradiz, é verdade também, de outro lado, que ao menos em um ponto essa filosofia tem razão: a contradição é insustentável, e por isso aquilo que se contradiz não é nada (Lebrun 8, p. 280). "O que, em geral, move o mundo", diz Hegel em citação de Lebrun, "é a contradição, e é ridículo dizer que a contradição não se deixa pensar. Eis somente o que há de correto nessa afirmação: que não se pode permanecer na contradição e que essa se suprime por si mesma" (id., ibid., p. 268). Eis aí o que falta em Sartre, de modo que o custo de pensar a pura contradição é permanecer enredado nela. Certamente, a contradição suprimida, em Hegel, não repõe a "identidade abstrata", e por isso o reconhecimento do acerto da filosofia do Entendimento só vai até esse ponto: que a contradição não se sustenta, que as crises devem ser resolvidas etc., e é essa possibilidade que não vislumbramos em Sartre, já que ali não há mediação possível.

Mas até que ponto essa crítica é justa? Será que ela não é ainda tributária de uma compreensão insuficiente do negativo? Parece que sim, pois, se é verdade que o negativo é vazio de ser, que ele é negação do ser, e que por isso ele é definitivamente seu contraditório, e que portanto não há "passagem" do nada ao ser, nem do ser ao nada, é verdade também que essa negação não é apenas negação do ser. Justamente por conta da exigência de pensar o nada em "estado puro" e de assegurar que o nada não "passa" no 
ser, Sartre pretende que a negação não seja posta como tal, o que a converteria em ser, em um simples contrário seu; daí por que ela deve ser também negação de si mesma: ela não é apenas negação do ser, mas, para ser uma pura negação, para não se pôr como ser, ainda que negativo, ela deve ser também negação de si mesma. Se eu dissesse que o nada, por vazio que seja, ao menos é, eu faria do nada um ser; daí por que, para que ele seja nada, ele deve se autonegar. ${ }^{(19)}$ Foi isso, acredita Sartre, que não se viu, e por isso o negativo jamais foi pensado em sua pureza. Ora, mas, nesse caso, não se trata apenas de assegurar uma contradição definitiva; trata-se também, de modo inédito, de descortinar uma superação - ou, em termos fenomenológicos, uma transcendência. A transcendência advém daí, desse envolver-se da negação consigo mesma, dessa recusa em se cristalizar, ainda que como negação. Pois é da negação de si mesma que surge a relação a si, a distância a si, a passagem além, em direção a um possível. Não é verdade que permanecemos enredados na contradição, sem superação possível. É a própria contradição, pensada até o fim, que nos assegura essa transcendência.

Que seja. No entanto, o leitor tem boas razões para questionar essa superação. Pois ela é inteiramente tributária de um retorno da negação sobre si mesma - o que significa dizer que ela não envolve o ser em si. Sem dúvida, o ser em si é justamente aquilo que é negado, mas não há imbricação entre as duas regiões de ser, não há mistura, o ser permanecendo o que é e o para si, perpétua negação do ser. O para si é uma transcendência contínua, movimento para diante de si mesmo, mas isso justamente porque ele resulta de uma negação que se pretende ainda mais radical do que a hegeliana, que o depura de toda coisificação, de todo compromisso com o em si. Se há transcendência, é preciso dizer contudo que ela não envolve mediação, pois, enfim, uma vez traçada essa rigorosa distinção, em que o ser é absoluta positividade e o nada é purificado, purificação continuada de tudo aquilo que ali se misture de ser (ser e nada entendidos então a partir dessa exclusão recíproca), uma vez traçada essa distinção, já não há compromisso possível, envolvimento, imbricação. Daí por que a antinomia entre realismo e idealismo simplesmente "desaparece", como aponta Merleau-Ponty, como se essa antinomia traduzisse apenas um problema mal colocado, aquele da 
"mistura" ou da "união", mas justamente "mistura e união são impossíveis entre o que é e o que não é" (Merleau-Ponty 11,p. 81-2). Pois se ser e nada são pensados em rigorosa distinção, por exclusão recíproca, isso também significa que um não pode ser pensado sem o outro. Ainda que o em si não exija o para si, como quer Sartre, o nada é inteiramente pensado por contradição ao em si, o que já é suficiente para insistir na estreita vinculação de ambos, ainda que ela parta do para si. Assim, a partir do momento em que a constituição cede lugar à negação, podemos dizer que, embora não haja mundo sem para si (nisso tem razão o idealista), a negação não modifica, não altera o isto, não acarreta nenhum tipo de relação real (o que o idealista não viu). Por outro lado, o mundo é o próprio ser (nisso tem razão o realista), já que o mundo é alguma coisa que acontece ao em si, mas ele é um nada acrescentado ao em si (o que o realista não viu). Tudo, enfim, consiste em pensar o negativo rigorosamente, até esse ponto limite em que os problemas da filosofia clássica, para usar ainda uma expressão de Merleau-Ponty, "se volatilizam" (id., ibid., p. 82). Daí o caráter peculiar da liberdade sartriana, que não admite nenhuma forma de condicionamento, nem do mundo, nem do passado: o inveterado jogador que decide livre e sinceramente não mais jogar sabe que sua resolução passada é totalmente ineficaz. Ele apreende a cada instante a ruptura do determinismo, apreende-se como separado daquele que foi - pois o para si é negação não apenas do ser, mas também de si mesma, ruptura permanente com tudo o que é dado. O jogador precisará a cada instante retomar sua decisão; e isso se fará sempre de novo a partir do nada e livremente. Ele terá outra vez de encontrar o medo de desolar a família, terá novamente de refazer a barreira entre ele e o jogo. Ele está só e nu diante da tentação; os muros e barreiras que pacientemente ergueu são impotentes para detê-lo, ele percebe com angústia que nada pode impedi-lo de jogar. Há aqui, certamente, tais motivos para a decisão, mas eles não são causas. Daí por que, segundo Sartre, o existencialista não crê na força da paixão, naquela idéia de uma torrente passional que nos arrasta incontinenti. Se digo que gosto tanto de um amigo a ponto de lhe sacrificar uma tal soma de dinheiro, terá sido a minha decisão de sacrificar-lhe essa soma que me permitirá dizer que eu gosto dele a esse ponto. Só se pode determinar o valor 
do afeto, do sentimento, da paixão, por um ato que o confirme (Sartre 14, p. 20). Noutras palavras, é a decisão que torna um motivo, motivo, não o inverso. Não há nenhuma passividade nessa liberdade, ela não é minimamente afetada por coisa alguma - e isso porque, na origem mesma da consciência, Sartre pôs uma negação. É por uma negação de si mesma, voltada sobre si mesma, que uma consciência é possível.

Haveria outro termo para esse pensamento que, partindo do negativo cartesiano, radicalizou-o a ponto de fazê-lo voltar-se sobre si mesmo - e que, ao fazê-lo, foi descobrir no Deus cartesiano o seu êmulo principal? Que se trate aqui de uma negação desconhecida pelo Deus de Descartes, isso importa pouco - pois o termo desse pensamento é aquele mesmo que, em Descartes (ao menos em uma de suas versões, como sugere Merleau-Ponty) (Merleau-Ponty 9, p. 26-7), é o próprio modelo da relação entre Deus e Natureza, entre naturante e naturado, modelo que concentra no naturante todo o sentido, toda a interioridade, ao naturado restando uma existência em si, sem orientação, sem interior, exterioridade pura. A transcendência de que fala Sartre, em que o ser é envolvido enquanto negado, apenas enquanto negado, sem sé misturar, portanto, sem se modificar, implica essa mesma ontologia dualista que não deixa à Natureza senão a repetição, jamais a produção de sentido.

Abstract: This paper deals with the Sartrean concept of denying so as to show its central position in Sartre's phenomenology.

Key-words: Sartre - denying - finiteness - freedom - phaenomenon 


\section{Notas}

(1) É o que observa, por exemplo, Livio Teixeira (Teixeira 17, p. 63). Vale notar, contudo, que, a essa altura, Livio Teixeira apenas reporta a tese de Gilson do "oportunismo" cartesiano. Para ele, ao contrário, é possível mostrar em Descartes uma "doutrina congruente" (id., ibid., p. 64). Voltaremos a isso adiante.

(2) "A verdade", diz Descartes em correspondência a Clerselier (23 de abril de 1649), citada por Sartre, "consiste no ser e a falsidade no não ser apenas" (Sartre 15, p. 328; Descartes 2, p. 356).

(3) Citação da carta a Mersenne de 6 de maio de 1630 (idem 3, p. 936).

(4) "A indiferença que convém à liberdade do homem é muito diferente daquela que convém à liberdade de Deus" (apud Teixeira 17, p. 62).

(5) Carta ao Padre Mesland de 2 de maio de 1644.

(6) "Se o idealismo e o realismo fracassam em explicar as relações que unem de fato essas regiões de direito incomunicáveis, que outra solução podemos dar ao problema?" (Sartre 13, p. 34).

(7) "Se a consciência, considerada em seu isolamento, é uma abstração, se os fenômenos são semelhantemente abstratos, enquanto eles não podem existir como fenômenos sem aparecer a uma consciência, o ser dos fenômenos, como em si que é o que é, não poderia ser considerado como uma abstração. Para ser, ele só tem necessidade de si mesmo, só remete a si mesmo" (id., ibid., p. 219).

(8) É a negação que vai estar na origem da consciência de si. Daí o caráter peculiar do negativo em Sartre. Voltaremos a isso quando discutirmos sua leitura de Hegel. 
(9) Sartre mostra essa negação voltada sobre si mesma pelo exemplo da máfé, que deve revelar, como condição de sua possibilidade, a unidade do ser e do não ser, o ser-para-não-ser, uma "íntima desagregação no seio do ser" da consciência (Sartre 13, p. 111). "Eu só posso tentar apreender-me como não sendo covarde, sendo-o, se este 'ser covarde' está 'em questão' no momento mesmo em que ele é, se é ele mesmo uma questão, se, no momento em que quero apreendê-lo, ele me escapa por todos os lados e se nadifica. A condição para que eu possa tentar um esforço de má-fé é que, em um sentido, eu não seja esse covarde que eu não quero ser. Mas, se eu não fosse covarde, no modo simples do não-ser-aquilo-que-não-se-é, eu seria de 'boafé', declarando que não sou covarde. Assim, essa covardia inapreensível, evanescente, que eu não sou, é preciso, também, que eu a seja de algum modo. E que não se entenda por isso que eu deva ser 'um pouco' covarde, no sentido em que 'um pouco' significa 'em uma certa medida covarde - em uma certa medida não covarde'. Não: é totalmente covarde, e sob todos os aspectos, que eu devo ser e não ser de uma só vez. Assim, nesse caso, a máfé exige que eu não seja o que sou, isto é, que haja uma diferença imponderável que separa o ser do não ser no modo de ser da realidade humana" (id., ibid., p. 107).

(10) Estrutura identificável nos três capítulos da segunda parte de O ser e o nada, respectivamente "As estruturas imediatas do para si", "A temporalidade" (ambos consideram a negação na perspectiva da negação de si) $e$ "A transcendência" (na perspectiva da negação do ser em si). Quanto à estrutura da primeira parte da obra, ocorre o inverso. É que, aqui, o método é o da descrição objetiva de condutas (id., ibid., p. 38), e, na segunda parte, o método é reflexivo.

(11) Veremos, no entanto, que o ser em si negado vai implicar certas características para o fenômeno - por onde Sartre pretende escapar ao "idealismo".

(12) A bem da verdade, não se pode dizer que o ser está presente: "Tínhamos estabelecido", diz Sartre referindo-se à Introdução da obra, "que o em si não podia jamais, por si mesmo, ser presença. Com efeito, o ser-presente 
é um modo de ser ek-stático do para si (...) a intuição é a presença da consciência à coisa" (Sartre 13, p. 221). Na Introdução, Sartre estabelecera que o fenômeno é "apelo de ser" (id., ibid., p. 16) e, por meio da "prova ontológica”, que ele é em si (id., ibid., p. 27 e ss.).

(13) "Designava-se no mundo antigo a coesão profunda e a dispersão do povo judeu pelo nome de 'diáspora'. É a palavra que vai nos servir para designar o modo de ser do para si: ele é diaspórico” (id., ibid., p. 182).

(14) É a expressão de Sartre ao falar de problema análogo, o da temporalidade fenomênica, do "tempo do mundo" (id., ibid., p. 255-7), não da temporalidade do para si.

(15) "A negação externa constitutiva do isto não pode parecer um caráter objetivo da coisa, se entendemos por objetivo aquilo que pertence por natureza ao em si-ou aquilo que, de uma maneira ou de outra, constitui realmente o objeto como ele é. Mas não devemos concluir daí que a negação externa tem uma existência subjetiva como puro modo de ser do para si" (id., ibid., p. 234).

(16) "[o em si] escapa à temporalidade. Ele é, e quando se desmorona nem sequer podemos dizer que ele não é mais. Ou, ao menos, é uma consciência que pode tomar consciência dele como não sendo mais, precisamente porque ela é temporal. Mas ele mesmo não existe como uma falta lá onde ele era: a plena positividade de ser se restaurou sobre seu desabamento. Ele era e agora outros seres são: eis tudo" (id., ibid., p. 34).

(17) Para fazer as citações, nos servimos também da tradução ainda inédita de Jair Lopes Barboza e Vinicius de Figueiredo.

(18) Sobre o uso dessa expressão ("identidade consigo mesmo"), vale aqui uma explicação. Diz Sartre: "A coincidência do idêntico é a verdadeira plenitude de ser, justamente porque nesta coincidência não é deixado nenhum lugar à negatividade. Sem dúvida, o princípio de identidade pode requerer o princípio de não contradição, como Hegel viu. O ser que é o que é deve poder ser o ser que não é o que não é. Mas, de início, essa negação, como 
todas as outras, vem à superfície do ser pela realidade humana (...) e não por uma dialética própria ao ser mesmo. Além disso, esse princípio pode denotar apenas as relações do ser com o exterior, pois justamente ele rege as relações do ser com o que ele não é. Trata-se, pois, de um princípio constitutivo das relações externas, tais como elas podem aparecer a uma realidade humana presente ao ser em si e engajado no mundo; ele não diz respeito às relações internas do ser; essas relações, enquanto elas poriam uma alteridade, não existem. O princípio de identidade é a negação de toda espécie de relação no seio do ser em si" (Sartre 13, p. 119-20). Daí por que, mais que afirmar uma identidade do ser consigo mesmo, Sartre prefere dizer que o ser é massivo, que ele é plena positividade, que ele não conhece alteridade, que ele não tem nenhuma relação com um outro ser, que ele é "demais para a eternidade" (id., ibid., p. 33-4).

(19) Quando digo que "X não é Y", que o tinteiro não é a mesa, X e Y permanecem intocados pela negação; temos então uma negação externa aos elementos envolvidos. Para que haja negação interna, negatividade pura voltada sobre si, ela tem que se fazer negação, portanto, ela não pode ser dada. Assim, a falta não é falta disso ou daquilo, o desejo não é desejo disso ou daquilo; para que ele seja radicalmente desejo, sem repleção possível, ele tem de se cavar como desejo: "Na medida em que o ser que falta de... não é o que lhe falta, nós apreendemos nele uma negação. Mas se essa negação não deve se desvanecer em pura exterioridade - e com ela toda possibilidade de negação em geral - seu fundamento está na necessidade para o ser que falta de... de ser o que lhe falta. Assim, o fundamento da negação é negação de negação. Mas essa negação-fundamento não é mais um dado que a falta de que ela é um momento essencial: ela é como tendo de $\operatorname{ser}($...) É somente como falta a suprimir que a falta pode ser falta interna para o para si e o para si só pode realizar sua própria falta tendo de sê-la, isto é, sendo projeto para sua supressão" (Sartre 13, p. 248-9). 


\section{Referências Bibliográficas}

1. DESCARTES, R. Meditações metafísicas. Col. Os Pensadores. São Paulo, Abril Cultural, 1983.

2. . Euvres de Descartes. Vol. V, Ed. Adam/Tannery. Paris, Vrin, 1996.

3. . Euvres et lettres. Bibliothèque de la Pléiade. Paris, Gallimard, 1987.

4. HUSSERL, E. $\sigma^{a}$ Investigação lógica. Col. Os Pensadores. São Paulo, Abril Cultural, 1980.

5 . Philosophie première. Paris, PUF, 1970.

6. KANT, I. Essai pour introduire en philosophie le concept de grandeur négative. Paris, Vrin, 1972.

7. LEBRUN, G. Kant e o fim da metafísica. São Paulo, Martins Fontes, 1993.

8. . La patience du concept. Paris, Gallimard, 1972.

9. MERLEAU-PONTY, M. La nature. Paris, Seuil, 1995.

10. . Signes. Paris, Gallimard, 1960.

11. . Le visible et l'invisible. Paris, Gallimard, 1996.

12. SARTRE, J.-P. Les carnets de la drôle de guerre. Paris, Gallimard, 1983.

13. . L'être et le néant. Paris, Gallimard, 1969.

14. . O existencialismo é um humanismo. Col. Os Pensadores. São Paulo, Abril, 1983.

15. . "La liberté cartesienne". In: Situations I. Paris, Gallimard, 1947. 
16. SIMONT, J. Jean-Paul Sartre. Un demi-siècle de liberté. Bruxelas, De Boeck \& Larcier, 1998.

17. TEIXEIRA, L. Ensaio sobre a moral de Descartes. São Paulo, Brasiliense, 1990. 